\title{
Az öntözéses gazdálkodásról szóló törvény a tájszemléletű vízgazdálkodás tükrében
}

\author{
The New Hungarian Act on Irrigation in the Light of a Landscape-Orientated \\ and Land-Use-Based Water Management
}

\begin{abstract}
ABSZTRAKT
Jelen tanulmány a vízszemléletü kormányzáshoz kapcsolódik, azon belül is leginkább egy sajátosan magyar problémakörhöz. Nevezetesen az Alföldön halmozottan jelentkező káreseményekhez (árvíz, aszály és belvíz), illetve a környezeti szolgáltatások helyzetéhez. A problémakör öszszetettségénél fogva a megoldás maga is csak rendszerszintü lehet, és ennélfogva az integrált és adaptív vízgazdálkodás keretében képzelhetö csak el. Ezen vízgazdálkodás magyar elnevezése egy, a Magyar Tudományos Akadémia keretében tevékenykedett kutatócsoport meghatározása alapján az ún. tájszemléletü vízgazdálkodás. A tájszemléletü vízgazdálkodás lehetséges megvalósitása újabban a mezőgazdasági öntözésfejlesztésnél vetődött fel. Jelen tanulmány újdonságát a nemrég elfogadott öntözéses gazdálkodásról szóló 2019. évi CXIII. törvény és annak hidrológiai, talajtani és jogtudományi szempontok alapulvételével történő értékelése adja.
\end{abstract}

Kulcsszavak: vízjog, öntözés, fenntarthatóság, vizek jó állapota, visszalépés tilalma, elővigyázatosság elve

\begin{abstract}
The present article relates to water governance, and within that a specific Hungarian problem, namely, the cumulative water-related damage occurring in the Great Plain (floods, droughts and inland water) and the ambiguous situation of environmental services. Due to the complexity of the problem, the solution itself can only be systematic and can therefore only be solved in the context of integrated and adaptive water management. In Hungarian, this water management is defined as landscape-oriented water management by a research group connected to the Hungarian Academy of Sciences. The possible implementation of landscape-oriented water management has recently emerged in connection with the development of agricultural irrigation. The novelty of this study is the assessment of the new Hungarian Act concerning the irrigation taking into account the different aspects of hydrology, pedology and jurisprudence.
\end{abstract}

Keywords: water law, irrigation, sustainability, good status of water, non-derogation principle, precautionary principle

* Dr. Szilágyi János Ede, egyetemi docens, Miskolci Egyetem Állam- és Jogtudományi Kar, civdrede@ uni-miskolc.hu. Dr. Dobos Endre, egyetemi docens, Miskolci Egyetem Földrajz-Geoinformatikai Intézet, ecodobos@uni-miskolc.hu. Dr. Szűcs Péter, egyetemi tanár, Miskolci Egyetem Környezetgazdálkodási Intézet és MTA-ME Műszaki Földtudományi Kutatócsoport, hgszucs@uni-miskolc.hu. 
Az Országgyülés 2019 végén fogadta el az öntözéses gazdálkodásról szóló 2019. évi CXIII. törvényt (Ötv. vagy öntözési törvény), a Kormány pedig 2020 júniusának végén az ennek végrehajtására kiadott 302/2020. (VI. 29.) kormányrendeletet (a továbbiakban: Ötvr.). Jelen tanulmány ${ }^{1}$ - amely egy korábbi közös szakcikk ${ }^{2}$ szerves folytatása - az új jogszabályok legfontosabb intézményeinek bemutatása mellett arra vállalkozik, hogy a jogszabályokat értékelje: egyrészt a mezőgazdasági öntözés rendszerszintủ revitalizációjának évek óta tartó állami intézkedéscsomagjának részeként, másrészt pedig egy átfogó kormányzási koncepció, - a tudományos közegben létező elnevezésével élve -, az ún. tájszemléletű vízgazdálkodás tükrében.

Mivel ez utóbbi koncepció sokak számára magyarázatot igényelhet, ezért tanulmányunk bevezetőjében érdemes röviden erre is kitérni:

A számos előzménnyel rendelkező tájszemléletủ vízgazdálkodás koncepciója e néven a Magyar Tudományos Akadémia A Nemzeti Víztudományi Kutatási Program kihívásai és feladatai címet viselő tudományos stratégiájában (továbbiakban: MTA 201[9] $)^{3}$ jelent meg, mintegy megoldási lehetőségként a Kvassay Jenő Terv (Nemzeti Vízstratégia; továbbiakban: KJT 2017) által felvetett azon kihívásokra, amelyek a területhasználatot újragondoló, a természetközeli vízjárás részleges helyreállítását, és egy természethez közeli (táj)gazdálkodás folytatását indokolnák - elsődlegesen, de közel sem kizárólagosan - az Alföld középső tájain halmozódó káresemények megoldása, illetve az ökoszisztéma-szolgáltatások fejlesztése érdekében (az ökoszisztéma-szolgáltatások mibenlétéről lásd Szilágyi 2018). A tájszemléletű vízgazdálkodás 'az integrált vízgazdálkodásba ágyazott adaptív vízgazdálkodás koncepciójának egy sajátos magyar továbbfejlesztése' (Szilágyi 2018), egy sajátságos magyar probléma-rendszerre adott válasz, amely ugyanakkor - a megfelelö korrekciókkal - más országok, területek vízgazdálkodási kihívásaira is alkalmazható. ${ }^{4}$

A tájszemléletű vízgazdálkodás koncepciójára részleteiben cikkünk későbbi részében térünk még vissza.

\footnotetext{
${ }^{1}$ A kutatómunka a Miskolc Egyetem Müszaki Földtudományi Karának GINOP-2.3.2-15-2016-00031 jelü „Innovatív megoldások a felszín alatti vízkészletek fenntartható hasznosítása érdekében" című projektjének részeként - a Széchenyi 2020 program keretében - az Európai Unió támogatásával, az Európai Strukturális és Beruházási Alapok társfinanszírozásával valósul meg. Jelen kézirat lezárásának ideje 2020. július 10.

2 SZILÁGYI János Ede-DoBos Endre-Szücs Péter: A tájszemléletủ vízgazdálkodás hidrogeológiai, talajtani és jogi aspektusai - Felhívás a tájszemléletủ vízgazdálkodás koncepció kimunkálásához. Hidrológiai Közlöny, 2020/1, 41-53.

${ }^{3}$ Az eredeti szövegben a tudományos stratégia egy korábbi, akkor véglegesnek gondolt, 2018-as verziója került hivatkozásra. Időközben azonban egy másik verzió jelent meg 2019-ben.

${ }^{4}$ A fenti idézetet a közelmúltban publikált közleményünkböl vettük: SzILÁGYI-DoBos-Szücs: i. m., 41. Az ott hivatkozott, e tanulmány mondanivalója szempontjából is releváns források adatai sorrendben a következők: Engloner Attila-Vargha Márta-Báldi András-Józsa János (szerk.): A Nemzeti Viztudományi Kutatási Program kihívásai és feladatai. MTA Ökológiai Kutatóközpont, Tihany, 2019. (a továbbiakban: MTA 2019); Kvassay Jenő Terv vagy Nemzeti Vízstratégia. A Nemzeti Vízstratégia és a végrehajtását biztosító intézkedési terv elfogadásáról szóló 1110/2017. (III. 7.) Korm. határozat alapján a KJT közzétételére a kormány honlapján került sor a Belügyminisztérium által 2017 áprilisában.; SzILÁGYI János Ede: Vízszemléletủ kormányzás - vízpolitika - vízjog. Miskolci Egyetemi Kiadó, Miskolc, 2018, 34. (http://real.mtak.hu/80278/) [a továbbiakban: SZILÁGYI (2018)].
} 


\section{A magyar mezögazdasági öntözés újragondolása az elmúlt évek állami intézkedései tükrében}

A mögöttünk álló évtized egyik vízgazdálkodási szempontból fontos elörelépése az volt, hogy az állam felismerte önnön felelősségét az érintett területeken, és egy aktívabb szerepvállalásba kezdett. ${ }^{5}$ Mindez igaz a mezőgazdasági öntözésre is, ${ }^{6}$ amelynek kapcsán szintén több érdemi intézkedés történt. ${ }^{7}$

Az egyik ilyen megoldásra váró kérdés volt az öntözővíz mezőgazdasági táblára juttatása más tulajdonában, használatában lévő ingatlano(ko)n keresztül, illetve az öntözővizet biztosító létesítményekhez való hozzáférés biztosítása. E problémakör rendezésének egyik szimbolikus törvénye volt a több vízgazdálkodási jogszabályt (így magát a vízgazdálkodásról szóló 1995. évi LVII. törvényt, a továbbiakban Vgtv.-t) is módosító 2013-as törvény (a továbbiakban: Módtv. 2013), illetve 2015-ös törvény ${ }^{9}$ (a továbbiakban: Módtv. 2015). A Módtv. $2013^{10}$ (a) változtatott a korábbi vagyonkezelői, üzemeltetői struktúrán, azáltal, hogy a forgalomképes állami létesítmények (így öntözési csatornák) vagyonkezelése átkerült a vízitársulatoktól a vízügyi igazgatóságokhoz, illetőleg (b) meghatározott határidőre megtörténhetett (b1) az önkormányzati tulajdonban lévő vízfolyások, csatornák üzemeltetésének felajánlása vízügyi igazgatóságnak, vagy (b2) a vízügyi igazgatóság vizsgálata alapján maga is kezdeményezhette a vízügyi hatóságnál a csatorna, vízfolyás üzemeltetőjeként történő kijelölését. A Módtv. 2015 a csatorna üzemeltetésének hatósági kijelölését lehetővé tette a Módtv. 2013-ban rögzített határidő lejárta után is. ${ }^{11}$ Mint a későbbiekben bemutatjuk, az öntözési törvény szintén tartalmaz hasonló rendelkezéseket, vagyis egyfajta folytatása a 2013-ban megkezdett folyamatoknak.

A táblák közötti vízátvezetés egy más jellegü megoldását tette lehetővé a földforgalmi törvény végrehajtására kibocsátott törvényben (Fétv. ${ }^{12}$ szabályozott öntözési szolgalom. A Fétv. ezen rendelkezése alapján a földhasználót a más használatában levő ingatlanon öntözési szolgalom illette meg, ha mezőgazdasági tevékeny-

${ }^{5}$ SzILÁGYI János Ede: Vízjog - Aktuális kihívások a vizek jogi szabályozásában. Miskolci Egyetem, Miskolc, 2013, 230-231. (http://real.mtak.hu/79658/).

${ }^{6}$ Ennek egyik legfrissebb tanúbizonysága az öntözésfejlesztéshez szükséges intézkedésekröl szóló 1664/2019. (XI. 25.) Korm. határozat, vagy a 35/2020. (III. 5.) Korm. rendelet, amely utóbbi éppen a felszín alatti vízkivétel kapcsán hozott új rendelkezéseket. Mindezek kapcsán lásd SzILÁGYI János Ede-BARANYAI Gábor-Szűcs Péter: A felszín alatti vízkivételek liberalizálása az Alaptörvény és az európai uniós jog tükrében. Hidrológiai Közlöny, 2017/4, 14-23.; Vesd össze: CsIRSzKı Martin Milán: „Green” legal interpretation in the light of a judgment of the Supreme Court. Journal of Agricultural and Environmental Law, 2020/28, 136-148. (DOI: 10.21029/JAEL.2020.28.136).

${ }^{7}$ Mindezekről lásd részleteiben SzILÁGYI János Ede: A mezőgazdasági öntözéssel összefüggő egyes jogi problémákról. Miskolci Jogi Szemle, 2015/1, 33-51. [a továbbiakban: SzILÁGYI (2015a)]; SzILÁGYI János Ede: Aktualitások a mezőgazdasági vízjog köréből. In: Gellén Klára (szerk.): Honori et virtuti. Ünnepi tanulmányok Bobvos Pál 65. születésnapjára. lurisperitus, Szeged, 2017, 423-434.

${ }^{8}$ Egyes törvények vízgazdálkodási tárgyú módosításáról szóló 2013. évi CCXLIX. törvény.

${ }^{9}$ Egyes vízgazdálkodási és tűzvédelmi tárgyú... törvények módosításáról szóló 2015. évi CXX. törvény.

10 Lásd a Vgtv. korábbi 45/D-G. §-ait.

11 Vgtv. 22/A-C. §.

${ }^{12}$ A mezö- és erdőgazdasági földek forgalmáról szóló 2013. évi CXXII. törvénnyel összefüggő egyes rendelkezésekről és átmeneti szabályokról szóló 2013. évi CCXII. törvény. 
sége folytatásához szükséges öntözés érdekében a víz odajuttatását, szétosztását, illetve annak elvezetését másként nem, vagy csak aránytalanul nagy nehézséggel, vagy költséggel lehetett biztosítani. ${ }^{13}$ Mint a későbbiekben kitérünk rá, az öntözési törvény más alapokra helyezte az öntözési szolgalmat is, immáron kivéve annak szabályozását a Fétv. alól.

Az öntözés kapcsán már a kezdetektől esszenciális kérdés volt a finanszírozásé. E pont kapcsán lényeges volt egyrészt az új vízi létesítményekhez kapcsolódó beruházások forrásai előteremtésének kérdése, és ehhez kapcsolódóan az esetleges támogatások ügye, másrészt ${ }^{14}$ pedig a vízszolgáltatás ellentételezéseként fizetendő mezőgazdasági vízszolgáltatási díj ügye. Előbbi kapcsán jó lehetőséget teremtettek az uniós források, ugyanakkor e támogatásokhoz való hozzáférés kapcsán is maradtak még lebontandó akadályok, amelyeket a jogalkotó jelentős részben az öntözési törvényben tételezett, öntözési közösségek kategóriájának bevezetésével kívánt orvosolni. ${ }^{15} \mathrm{~A}$ mezőgazdasági vízszolgáltatás díját ${ }^{16}$ illetően a jogalkotó az eredetileg elgondolt - a termelők számára jelentősebb kedvezményt tartalmazó díjképzéshez képest pár évvel ezelőtt új képlet bevezetése mellett döntött, feltételezhetően azon célból, hogy így nagyobb összhangba hozza a magyar szabályozást az európai uniós Víz-keretirányelvben tételezett költségmegtérülés elvével. ${ }^{17}$

A fenti intézkedésekhez hasonlóan fontos kérdés volt az is, hogy a kormányzaton belül az öntözésfejlesztésnek legyen egy hatékony koordinációs mechanizmusa, szerve. Az átszervezések kezdetén mindezt - a két világháború között Magyarországon müködő, történeti példából kiindulva - egy öntözési hivatal felállításával kívánta elérni a kormányzat. Végül az elképzelés a 2019. július 1. napjával kialakításra került Nemzeti Földügyi Központ (NFK) keretében látszik megvalósulni. ${ }^{18}$ Az öntözési törvény, mint öntözési igazgatási szervnek számos fontos feladatot rendel e szervnek, amelyekkel alább szintén foglalkozunk.

${ }^{13}$ Lásd a Fétv. eredeti, az öntözési törvénnyel hatályon kívül helyezett 26 . §-át. Az öntözéssel kapcsolatban fontos rendelkezéseket, kedvezményeket tartalmaznak a mezőgazdasági földek tulajdoni, használati, illetve hasznosítási kérdéseit rendező más jogszabályok is; lásd például a mező- és erdőgazdasági földek forgalmáról szóló 2013. évi CXXII. törvény 13. §, a termőföld védelméröl szóló 2007. évi CXXIX. törvény 21. és 23. §. A korábbi szabályok elemzését lásd SzILÁGYI (2015a): i. m., 40.

${ }^{14}$ Fontos kérdés továbbá a vízkészletjárulék is. Ennek kapcsán lásd különösen: Vgtv. 15/A. § (1), 15/C. (1) bekezdés I) pont, 15/C. § (1) bekezdés $m$ )-n) pontok, (1a)-(2). Lásd még: Vgtv. 15/E. § (1)-(1a), 43/1999. KHVM R. 5. § (1) bekezdés i) pont, 9/A-B. §, 1. melléklet 1. e) pont.

${ }^{15}$ Erröl részleteiben lásd még a T/7845. számú törvényjavaslatot, benyújtás dátuma: 2019. 10. 29., részletes indoklás 9-11. §, 13. [a továbbiakban: T/7845. OGY iromány].

${ }^{16}$ Erről lásd: Vgtv. 15/F. §, 115/2014. (IV. 3.) Korm. rendelet a mezőgazdasági vízszolgáltatás díjképzési rendjéről.

${ }^{17}$ Mindennek részleteiről lásd: SzILÁGYI János Ede: Az uniós Víz-keretirányelv költségmegtérülésének elve az Európai Bíróság esetjogának tükrében. In: Szalma József (szerk.): A Magyar Tudomány Napja Délvidéken 2014, VMMT, Újvidék, 2015, 212-226. Vesd össze a 2014-2020 közötti források felhasználásának előfeltételeiként meghatározott, a víz szektort érintő előzetes feltételek teljesítéséről szóló 1121/2014. (III. 6.) Korm. határozattal.

${ }^{18}$ Lásd az NFK feladatairól szóló 158/2019. Korm. rendeletet és az NFK Szervezeti és Működési Szabályzatáról szóló 1/2019. NFK utasítást. 


\section{Az öntözési törvény}

A 2019. december 10. napján elfogadott öntözési törvény egyrészt számos önálló jogintézményt foglal magában, másrészt pedig más törvények előírásainak módosítása is e törvényben került szabályozásra. A jogalkotó a törvényi szintű szabályozást nem igénylő kérdéseket az Ötvr.-ben rendezte, illetve annak elfogadásakor jelentős részben módosította, kiegészítette a környezeti hatásvizsgálati és az egységes környezethasználati engedélyezési eljárásról szóló 314/2005. (XII. 25.) kormányrendeletet (a továbbiakban: Khvr.) is.

Az új törvény elfogadásának eredője a mezőgazdasági termelők „öntözési hajlandóságának" fokozása. ${ }^{19} \mathrm{E}$ potenciális hajlandóságot fokozó eszközök közül az öntözési törvény különösen (de nem kizárólagosan) az alábbi intézmények keretszabályainak lefektetésére fókuszál.

(a) Az öntözési törvény több rendelkezése is a vízátvezetés hatékonyabbá tételét hivatott szolgálni. Ide tartozik (a1) az öntözési szolgalom újraszabályozása, ${ }^{20}$ amely ez idáig a Fétv.-ben volt megtalálható. Ezen intézmény egyik fontos eredője, hogy az „öntözés, habár nem tekinthető az állam vagy önkormányzat által ellátandó kötelező feladatnak, azonban az öntözéses gazdálkodás közérdek". ${ }^{21}$ Az öntözéses gazdálkodás folytatása érdekében a vízi létesítmény vízjogi engedélyese öntözési szolgalomra ${ }^{22}$ jogosult, ha az a szolgáló ingatlan rendeltetésszerü használatát nem zárja ki. ${ }^{23} \mathrm{Az}$ öntözési szolgalom a vízjogi engedélyben meghatározott engedélyest addig illeti meg, amíg a vízjogi engedély alapján folytatja tevékenységét. Az öntözési szolgalmat a vízügyi hatóság a vízjogi létesítési vagy üzemeltetési engedélyben alapítja. ${ }^{24} \mathrm{Az}$ ingatlan tulajdonosát a korlátozás mértékének megfelelő kártalanítás illeti meg; a vízügyi hatóság határozatában rendelkezik az ingatlan tulajdonosát megillető kártalanításról, amelyet a vízjogi engedélyes térít meg az ingatlan tulajdonosának. ${ }^{25}$ Fontos kiemelni, hogy az Ötv. e szabálya precedenst teremtett azzal, hogy a kártalanítás ténye mellett annak (Ötvr.-ben meghatározott) mértékét is az állam határozza meg két gazdasági szereplő között. Szintén a vízátvezetést hivatott segíteni (a2) a meglévő, vízjogi engedély alapján üzemelő harmadlagos műhöz ${ }^{26}$ történő

19 T/7845. OGY iromány, általános indoklás, 9.

${ }^{20}$ Ennek részletes szabályait az Ötv. 15. § (2) c) pontjának felhatalmazása alapján kormányrendeletben rendezi a jogalkotó.

21 T/7845. OGY iromány, részletes indoklás 2-3. §, 10. Fontos megjegyezni ugyanakkor, hogy ez a fogalom a törvény normaszövegében már nem jelenik meg.

22 E szolgalom alapján a szolgáló ingatlan tulajdonosa, használója köteles tűrni, hogy az ingatlanán az öntözéses gazdálkodást folytató mezőgazdasági termelő a mezőgazdasági tevékenysége folytatásához szükséges öntözést szolgáló vonalas vízi létesítményt létesítsen és üzemeltessen, az ehhez szükséges vízi munkákat elvégezze, illetve az öntözőberendezést átvezesse; Ötv. 2. § (1).

${ }^{23}$ Ezt hivatott szolgálni az Ötvr. azon szabályozása is, amely alapján a kérelmezőnek egyeztetést kell tartania az öntözési szolgalommal terhelni kívánt ingatlanok tulajdonosaival és használóival annak érdekében, hogy az öntözési szolgalom nyomvonala olyan módon kerüljön meghatározásra, ami az érintett ingatlan rendeltetésszerủ használatát nem zárja ki és kizárólag a szükséges mértékben korlátozza; Ötvr. 1-2. §.

24 Ötv. 2. §, Ötvr. 3-4. §.

25 Ötv. 3. §, Ötvr. 5-6. §.

${ }^{26}$ Harmadlagos mú: a vízügyi igazgatási szervek által kezelt és üzemeltetett vízi létesítmény, valamint a mezőgazdasági öntözési igények tényleges felmerülésének helye között elhelyezkedő üzemi szintű mezőgazdasági vízellátást biztosító, öntözési célú vagy kettős működésű vízi létesítmény; Ötv 1. § 1. pont. 
csatlakozás szabályozása is. Erre akkor van lehetősége bármely mezőgazdasági termelőnek, ha az üzemeltető engedélyes hozzájárul; mindez vízjogi engedély alapján történik, és a csatlakozó termelő vízhasználattal kapcsolatos érdekeltsége arányában vállalja a szükséges értékmegtérítést, illetve költségtérítést. ${ }^{27} A$ vízátvezetés hatékonyabbá tételét szolgálhatja azon rendelkezés is, amely alapján (a3) a helyi önkormányzat a tulajdonában álló harmadlagos mü tulajdonosi jogainak gyakorlását átadhatja az államnak. ${ }^{28} \mathrm{Az}$ állam képviseletében az öntözési igazgatási szerv jár el. Az öntözési igazgatási szerv szakmailag ellenőrzi a helyi önkormányzattól érkező átadó nyilatkozatot abból a szempontból, hogy az átadandó harmadlagos mü öntözési célokat szolgál-e öntözési közösség számára (az öntözési közösségről lásd alább). Ha az öntözési igazgatási szerv a szakmai ellenőrzés eredményeképpen megállapítja, hogy az átadandó harmadlagos mü öntözési közösség számára szolgáltat vizet, akkor az öntözési igazgatási szerv a harmadlagos mü tulajdonosával - az üzemeltetési és fenntartási feladatok átvállalásáról - ingyenes szerződést köt. A tulajdonosi joggyakorlás keretében az öntözési igazgatási szerv a harmadlagos müvet maga üzemelteti, vagy - ha az adott harmadlagos müvel ellátott területek öntözése ezáltal hatékonyabban, és pénzügyileg kedvezőbben biztosítható - bérleti, haszonbérleti, vállalkozási szerződés alapján hasznosításra átengedheti vagy vagyonkezelésbe adhatja; ${ }^{29}$ az öntözési törvény előterjesztőinek szándéka szerint így például az „öntözési közösségek jogosultak az öntözési körzeten belül található harmadlagos müvek üzemeltetésére”. ${ }^{30}$ Az öntözési igazgatási szerv nem jogosult a tulajdonosi joggyakorlás keretében a harmadlagos mủ tulajdonjogának átruházására. ${ }^{31}$

(b) Az öntözéses gazdálkodás kivitelezésének új, alulról szerveződő koordinációs közösségei az öntözési közösségek, amelyeket az öntözési törvény az osztrák öntözési szövetkezetek mintájára hozott létre. ${ }^{32}$ Öntözési közösségként olyan (i) gazdasági társaság vagy szövetkezet ismerhető el, ${ }^{33}$ amelynek tagjai az öntözési körzet területén található földrészlet használati jogával rendelkező mezőgazdasági termelők, ${ }^{34}$ illetve olyan (ii) termelői csoport, ${ }^{35}$ amely társaság, szövetkezet vagy csoport az öntözési körzet területén szántóföldi növénytermesztés és ipari zöldségtermesztés esetén legalább 100 hektár, kertészeti zöldség-gyümölcstermesztés esetén legalább 10 hektár öntözésének lehetőségét biztosítja. ${ }^{36} \mathrm{Az}$ öntözési közösségek elismerése iránti kérelmeket az öntözési igazgatási szervhez kell benyújtani, aki a kérelmeket a szakmai véleményével együtt felterjeszti az agrárpolitikáért felelős miniszternek. Az öntözési közösségeket a miniszter ismeri el. ${ }^{37}$ Az öntözési közösségek alapítását

27 Ötv. 4. §.

${ }^{28}$ Ötv. 12. § (1)-(3).

29 Ötv. 12. § (5).

$30 \mathrm{~T} / 7845$. OGY iromány, részletes indoklás 9-11. §, 13.

31 Ötv. 12. § (5).

32 T/7845. OGY iromány, részletes indoklás 9-11. §, 13.

${ }^{33}$ Az elismerés részletes szabályait az Ötv. 15. § (2) b) pontjának felhatalmazása alapján kormányrendeletben rendezi a jogalkotó.

${ }^{34}$ Ötv. 7. § (1).

35 Ötv. 7. § (3).

36 Ötv. 7. § (2).

37 Ötv. 8. § (1)-(2); Ötvr. 7-11. §. 
ösztönzendő a „Vidékfejlesztési Programban új pályázati felhívás lesz az öntözési közösségek támogatására, amely 90 százalékos intenzitással támogatja az engedélyezéshez szükséges vízjogi tervek, dokumentációk elkészítését”. ${ }^{38}$ Az Agrárminisztérium 2020. májusi nyilatkozata alapján „52 közösségi szerveződés van az agrárminisztérium 'látókörében', és [...] új intézkedésként támogatják az öntözési közösségek megalakulását”. Ugyanezen minisztériumi közlemény szerint az első ilyen öntözési közösség Hartán jött létre:

Az ország első, hartai öntözési közösségének tagjai társas vállalkozások, családi gazdaságok és termelői csoportok, amelyeket az Agro-Harta Zrt., a közösség egyik fö gazdálkodója, integrátora, egyben a vízház tulajdonosa lát el öntözővízzel. Az öntöző távcsatorna állami tulajdonba és a Nemzeti Földügyi Központ tulajdonosi joggyakorlása alá került. A közösség öntözési területe mellett található csatorna megvásárlását követően a régi elhanyagolt, jelentősen feliszapolódott szakasz teljes hosszában, több mint 4 kilométeren megújult. A távcsatorna azonban nemcsak az öntözővíz szivattyúházhoz történő zavartalan eljutásához, hanem a víz visszatartásához, megőrzéséhez, a megnövekedett öntözési igények ellátásához, akár a belvíz elvezetéséhez is hozzájárul. A közösség 500-600 hektáron öntöz hat, korszerü körforgó öntözőberendezéssel intenzív termesztésű növényeket, föként zöldborsót, fö- és másodvetésü csemegekukoricát. A föld alatt 36 kilométer csővezeték fut, üzemeltetési engedélyük 1000 hektárra szól és 1 millió köbméter víz kivételére ad lehetőséget. A távcsatorna felújítása, első ütemben 200 hektár, majd második lépcsőben további 500 hektár öntözhetővé tételét teszi lehetővé a Hartai Öntözési Közösség számára. ${ }^{39}$

(c) A tájszemléletű vízgazdálkodás szempontjából leginkább érdekes intézményeket - az öntözési törvény előterjesztési anyagai alapján ${ }^{40}$ - az adminisztrációs terhek csökkentésének igénye szülte, vagyis elsődlegesen nem maga a tájszemléletű vízgazdálkodás koncepciójának való megfelelés. E két intézmény az öntözésfejlesztési terv, illetve - annak hiányában, illetve attól eltérést biztosítandó - a körzeti környezeti terv;"11 a kettő különböző kiterjedésű területi egységre vonatkozik: az előbbinek az ún. öntözési kerület, ${ }^{42}$ utóbbinak pedig az ún. öntözési körzet ${ }^{43}$ jelenti a területi hatályát. Az öntözési kerületeket hivatalból az öntözési igazgatási szerv jelöli ki a vízgyűjtő-gazdálkodási tervezési alegységek, a talajtani és vízföldtani adottságok, a domborzati és a vízrajzi viszonyok és az öntözés gazdaságossága figyelembevé-

\footnotetext{
38 TASNÁDI Gabriella: Az öntözési törvény legfontosabb elemei, https://www.nak.hu/tajekoztatasi-szolgaltatas/ mezogazdasagi-termeles/101047-az-ontozesi-torveny-legfontosabb-elemei (2020. 01. 08.).

${ }^{39}$ Agrárminisztérium Sajtóiroda: Az öntözés a biztonságos élelmiszerellátás alapja. Sajtóközlemény, 2020. 05. 15. https://www.kormany.hu/hu/foldmuvelesugyi-miniszterium/hirek/az-ontozes-a-biztonsagos-elelmiszerellatasalapja (2020. 05. 17.).

40 T/7845. OGY iromány, általános indoklás, 9.

${ }^{41}$ Ezek részletes szabályait az Ötv. 15. § (2) a) pontjának felhatalmazása alapján kormányrendeletben rendezi a jogalkotó.

42 Öntözési kerület: az öntözési igazgatási szerv által hivatalból kijelölt, középszintű tervezési egység, amely több öntözési körzetet foglalhat magába; Ötv. 1. § 4. pont.

43 Öntözési körzet: az öntözési közösség működésére szolgáló terület, amely az öntözési közösség tagjai által öntözni kívánt földterületeket, valamint a közösség tagjai használatában nem álló közbeékelődött területeket foglalja magába, amelyeket az öntözési közösség elismeréséröl szóló döntés tartalmaz; Ötv. 1. § 5. pont.
} 
telével az öntözési célú vízi létesítmény hatásterületének megfelelöen (egy földrészlet csak egy öntözési kerület része lehet). ${ }^{44} \mathrm{Az}$ öntözési körzet területi egység maga lényegében az érintett öntözési közösséggel jön létre akként, hogy a miniszter az öntözési közösség elismerésében jelöli ki azt a vízrajzi, vízföldtani, domborzati viszonyok figyelembevételével, az öntözési kerület határain belül. ${ }^{45}$ (Az öntözési körzetet úgy kell kijelölni, hogy az öntözési közösség céljainak biztosítása mellett a lehető legkevesebb földrészletre terjedjen ki. „Az öntözési körzet területe nem fedhet másik öntözési körzet területére" [sic!] ${ }^{46}$ )

Az Ötvr. rendelkezéseit látva - vagyis, hogy abban egyelöre csak a körzeti környezeti tervvel kapcsolatosan találhatunk részletszabályokat - megállapíthatjuk, hogy a jogalkotó első körben az öntözési körzetekkel, vagyis a kisebb részegységek létrehozásával számol, illetve azokra koncentrál.

(c1) Az öntözésfejlesztési terveket az öntözési igazgatási szerv az öntözési kerületek területére készíti el, amely tervek a hatósági jóváhagyással válnak érvényessé. Az öntözésfejlesztési terv tartalmazza az öntözési kerületben az öntözéssel összefüggő természeti feltételeket, a domborzati, vízrajzi, vízföldtani és talajtani adottságokat, amelyek figyelembevételével az öntözési igazgatási szerv meghatározza, hogy a kijelölt területen milyen természetvédelmi, környezetvédelmi, talajvédelmi, halgazdálkodási, erdőgazdálkodási és bányászati feltételekkel lehetséges az öntözéses gazdálkodás folytatása. Az öntözésfejlesztési tervnek megfelelö öntözéses beruházáshoz és az öntözésfejlesztési tervben meghatározott feltételek szerint történő öntözéses gazdálkodás végzéséhez nem kell lefolytatni a környezetvédelmi, természetvédelmi, talajvédelmi, halgazdálkodási, erdőgazdálkodási és bányászati engedélyezési vagy szakhatósági eljárást. Az öntözésfejlesztési terv a benne meghatározott természetvédelmi, környezetvédelmi, talajvédelmi, halgazdálkodási, erdőgazdálkodási és bányászati előírások tekintetében hatósági engedélynek vagy szakhatósági állásfoglalásnak minősül. Az öntözésfejlesztési terv a kiadásától számított 20 évig hatályos. Az öntözési kerületek kijelölését és az öntözésfejlesztési terveket a kormányzati honlapon közzé kell tenni. Az öntözési kerületeket és az öntözésfejlesztési terveket rendszeresen felül kell vizsgálni és módosítani kell, ha a kijelölés szempontjai vagy a természetvédelmi, vízgazdálkodási, környezetvédelmi, talajvédelmi, halgazdálkodási, erdőgazdálkodási és bányászati feltételek megváltoztak. ${ }^{47}$

(c2) Az öntözési körzetekhez kapcsolódó körzeti környezeti tervek elkészítésére két esetben kerülhet sor: egyrészt abban az esetben, amíg az érintett földrészletek vonatkozásában nincs hatályos öntözésfejlesztési terv, másrészt pedig ha - van ugyan ilyen öntözésfejlesztési terv, de - az érintett földrészletek vonatkozásában a hatályos öntözésfejlesztési tervben meghatározott feltételektöl el kívánnak térni. ${ }^{48}$ Az öntözési igazgatási szerv által készített ${ }^{49}$ környezeti körzeti terv hasonló - ugyan-

\footnotetext{
${ }^{44}$ Ötv. 5. §.

${ }^{45}$ Ötv. 9. § (1); Ötvr. 8. § (3); Khvr. 5/D. § (3).

${ }^{46}$ Ötv. 9. § (2)

47 Ötv. 6. §.

48 Ötv. 10. § (1).

${ }^{49}$ Ötv. 10. § (1).
} 
akkor szükebb körü - mentesülést biztosít a mezőgazdasági termelök számára, mint az öntözésfejlesztési terv: az öntözési beruházásra vonatkozó környezetvédelmi, természetvédelmi és talajvédelmi elóírásokat a környezeti körzeti terv tartalmazza, és amely - az Ötvr. rendelkezései alapján környezetvédelmi ${ }^{50}$ - hatóság jóváhagyásával válik érvényessé. E ponton fontos kiemelni tehát, hogy a tervet előzetesen a környezetvédelmi hatóság 'érvényesíti', és ezt követően minősül (környezetvédelmi) engedélynek vagy szakhatósági állásfoglalásnak (küszöb alatti hatásnál). Tehát valójában nem maga a terv minősül engedélynek vagy szakhatósági állásfoglalásnak.

A környezeti körzeti terv a benne meghatározott környezetvédelmi, természetvédelmi és talajvédelmi előírások tekintetében hatósági engedélynek vagy szakhatósági állásfoglalásnak minősül. A környezeti körzeti tervnek megfelelö öntözéses beruházás és a környezeti körzeti tervben meghatározott feltételek szerint történő öntözéses gazdálkodás végzéséhez nem kell lefolytatni a környezetvédelmi, természetvédelmi és talajvédelmi engedélyezési vagy szakhatósági eljárást. A környezeti körzeti terv a kiadásától számított 20 évig hatályos. A környezeti körzeti terveket rendszeresen felül kell vizsgálni és módosítani kell, ha a környezetvédelmi, természetvédelmi és talajvédelmi feltételek megváltoztak. Az öntözésfejlesztési terv hatálybalépését követöen a környezeti körzeti tervnek az öntözésfejlesztési tervben meghatározott feltételeknek megfelelő részei hatályukat vesztik. ${ }^{51}$

A mezőgazdasági termelök adminisztrációs terheit csökkenthetik továbbá az Ötv. azon rendelkezései, ${ }^{52}$ amelyek alapján az öntözési igazgatási szerv megbízás alapján képviselheti az öntözési közösséget, illetve az öntözési törvénynek megfelelö öntözési beruházást kezdeményező mezőgazdasági termelőt a vízjogi engedélyezési eljárásban, ha a beruházás megfelel az öntözésfejlesztési tervnek. Hasonló könnyítést jelent az is, hogy az öntözési közösség gondoskodhat a tagjai számára - meghatalmazás alapján - az öntözéshez szükséges engedélyek megszerzéséröl. ${ }^{53}$

(d) A tájszemléletủ vízgazdálkodás szempontjából is releváns lehet az, hogy az öntözési törvény jogosítványokat ad különböző szervezeteknek az öntözést érintő információk vonatkozásában, ami segítheti a tájszemléletű vízgazdálkodáshoz nélkülözhetetlen, rendszerszintü ismeretek összekapcsolódását. ${ }^{54}$

\section{Az öntözési törvény és a mögöttes elképzelések, a tájszemléletű vízgazdálkodás tükrében}

A tájszemléletủ vízgazdálkodás koncepciójával korábbi közös munkánkban részleteiben foglalkoztunk. Az ott leírtakat nem kívánjuk megismételni, azok megállapításaiból pusztán a legfontosabbakra utalunk, előrevetítve azt, hogy a tájszemléletü vízgazdálkodás

\footnotetext{
50 Lásd az Ötvr. eredeti 14. §-át.

51 Ötv. 10. $§(2)-(4)$.

52 Ötv. 11. §.

${ }^{53}$ Az öntözési törvény előterjesztőinek szándéka szerint a „közösségek jogosultak továbbá arra, hogy a beruházásaik nemzetgazdasági szempontból kiemeltté történő nyilvánítását kezdeményezzék annak érdekében, hogy a hatósági eljárások gyorsabban folyjanak le"; T/7845. OGY iromány, részletes indoklás 9-11. §, 13.

54 Ötv. 13-14. §.
} 
elnevezés nem valami új - a magyar vízszakma számára ismeretlen - megoldást foglal magában, hanem sokkal inkább számos olyan elgondolás számára kínál egyfajta ernyő-koncepciót, amelyek már korábban is feltűntek a legkülönbözőbb stratégiai dokumentumokban, illetve a legkülönbözőbb szerzők tollából [...] az egyes dokumentumok (illetve ugyanez igaz az egyes szerzőkre is) a tájszemléletű vízgazdálkodás kapcsán nem feltétlenül ugyanazokat az elemeket emelték ki, illetve tartották hangsúlyosnak, vagyis e vonatkozásban a tájszemléletű vízgazdálkodás koncepciója sem tekinthető lezártnak, és egységesnek. ${ }^{55}$

A tájszemléletű vízgazdálkodás legfontosabb elemei az alábbi pontokba süríthetők össze (a kapcsolódó szakpolitikai és szakirodalmi háttér részletesebb feldolgozásáról lásd korábbi cikkünk vonatkozó részeit ${ }^{56}$ ):

(a) A tájszemléletű vízgazdálkodás koncepciójának megvalósítását számos más szakpolitika igényeinek, illetve problémafelvetéseinek is formálnia kell. Vagyis a tájszemléletű vízgazdálkodás koncepciójának megvalósítása csak egy tágabb viszonyrendszerben - a fenntartható fejlődés hármas dimenziójában értő módon elhelyezve - lehet csak sikeres, amely elképzelhetetlen egy jól működtetett vízszemléletü kormányzás (water governance) nélkül, ${ }^{57}$ vagyis a vízpolitikán és vízgazdálkodáson túlmutató, nagyobb rendszer keretein belül kell tanulmányunk koncepcióját is kezelni. Különösen nagy az áthidalásra szoruló szakadék e vonatkozásban is a környezetvédelmi-természetvédelmi érdekek, és a növekedési kényszerben lévő gazdaságpolitikai érdek között.

(b) Magyarországi sajátosság, hogy a három jelentős magyarországi vízkáresemény (árvíz, belvíz, aszály) által érintett, sújtott területek között jelentős átfedések vannak; ugyan nem pusztán a Tisza vízgyüjtőjén, azonban területi nagyságrendjét tekintve ott kiemelkedően..$^{58}$

(c) A magyar vízgazdálkodásban éppen a fenti problémarendszert látva alakult ki az az álláspont, ${ }^{59}$ amely a Tisza 19 . századi szabályozásának nem várt következményeként tekint a vízhez kötődő káresemények kumulációjára. A komplex problémarendszer orvoslása értelemszerüen csak komplex szemlélettel történhet meg. A KJT $2017^{60}$ e komplexitásra utalva fejti ki, hogy „a vízpolitika és a vízgazdálkodás elválaszthatatlan a terület- és tájhasználattól... vízállapotokkal szembeni igények nagyrészt területhasználat formájában jelennek meg”. ${ }^{61}$

\footnotetext{
55 SZILÁGYI-DOBOS-SZŰCS: i. m., 42.

56 SZILÁGYI-DoBos-SzÜcs: i. m., 42-43.

${ }^{57}$ Lásd erröl: World Water Assessment Programme. Water for People. Water for Life. The United Nations World Water Development Report, UNESCO-Berghahn Books, 2003; MTA 2019; SZILÁGYI (2018): i. m.

${ }^{58}$ Mindezekhez kapcsolódóan fontosnak tartjuk megjegyezni azt is, hogy a klímaváltozás és az édesvízhez kapcsolódó kockázatok (például árvíz) mértéke között nagyon szoros összefüggés van (lásd Climate Change 2014: Contribution of Working Group II to the Fifth Assessment Report of the IPCC. Cambridge University Press, Cambridge-New York), nagymértékben betudhatóan azon feltételezésnek is, amely szerint a klímaváltozás felgyorsítja a hidrológiai ciklust (World Water Assessment Programme. Water in a changing World. The United Nations World Water Development Report 3, UNESCO-Earthscan, Paris-London, 2009).

${ }^{59}$ Például: Somlyódy László (szerk.): Magyarország vízgazdálkodása. Köztestületi Stratégiai Program, MTA, Budapest, 2011, 26-27.

${ }^{60}$ Kvassay Jenő Terv vagy Nemzeti Vízstratégia. A Nemzeti Vízstratégia és a végrehajtását biztosító intézkedési terv elfogadásáról szóló 1110/2017. (III. 7.) Korm. határozat alapján a KJT közzétételére a kormány honlapján került sor a Belügyminisztérium által 2017 áprilisában.

61 KJT 2017, 22., 62.
} 
(d) A helyzet egyfajta orvoslására (is) hivatott Vásárhelyi Terv Továbbfejlesztése ${ }^{62}$ (továbbiakban: VTT) azonban mindezt nem tudta maradéktalanul megvalósítani. Az, hogy ez idáig a tájszemléletű vízgazdálkodás koncepciójának megvalósítása nem történhetett meg a maga komplexitásában - például az Alföld területhasználatát grandiózusabb mértékben átszabó formában -, jelentős részben betudható az érintett települések struktúrájának átalakításával, illetve az infrastrukturális hálózatok jelentős módosításával együtt járó nagyarányú költségeknek is. A tájszemléletü vízgazdálkodás koncepciója ebből a perspektívából tekintve tekinthető a VTT újragondolásának is.

(e) A problémarendszerre válaszul - felismerve a vízgazdálkodás zöld infrastruktúráiban, illetve infrastruktúra nélküli intézményeiben (utóbbihoz sorolhatók a jogi eszközök is) rejlő lehetőségeket ${ }^{63}$ - a védmüvek korlátlan fejlesztése helyett bizonyos helyeken érdemes megfontolni a természetközeli vízjárás részleges helyreállítását, és egy természethez közeli (táj)gazdálkodás folytatását. ${ }^{64}$ Mindezzel lényegében azt kellene elérnünk, hogy a Magyarországra - például árvíz formájában - érkező többlet vízmennyiséget az ország határain belül megtartsuk azon időszakokra, amikor az időjárás okán egyébként szükében lennénk a víznek. A vízvisszatartás kapcsán a tájszemléletű vízgazdálkodás koncepciója változatos eszközöket céloz alkalmazni, és nem pusztán a védmüvek, mesterséges tározók alkalmazásán alapul. ${ }^{65} \mathrm{Az}$ aszály elleni fellépés kapcsán például fontos kiemelni, hogy annak vonatkozásában sem pusztán az öntözést tekintik egyedüli eszköznek a témát taglaló szerzők és dokumentumok - tipikusan a területhasználat-váltást hozzák fel egy fontos lehetőségként ${ }^{66}$-, egyúttal az öntözés jelenlegi gyakorlata kapcsán is továbbfejlesztést sürgetnek. ${ }^{67}$ A tájszemléletű vízgazdálkodás optimális megvalósítása esetén egyébiránt igaz lehet akár az a kijelentés is, hogy e koncepcióban nem az öntözés a mezőgazdasági vízigény kielégítésének elsődleges módszere; vagyis, hogy itt jó esetben táji szinten valósul meg a vízháztartás kiegyensúlyozása.

(f) Hangsúlyozandó, hogy a tájszemléletű vízgazdálkodás túlmutat egy adott folyóhoz köthető hullámtéren, nagyvízi medren és azoknál jelentősebb területet

${ }^{62}$ Ennek jogszabályi hátteréröl lásd különösen a Tisza-völgy árvízi biztonságának növelését, valamint az érintett térség terület- és vidékfejlesztését szolgáló program (a Vásárhelyi-terv továbbfejlesztése) közérdeküségéről és megvalósításáról szóló 2004. évi LXVII. törvényt, valamint a Duna és a Tisza árvízvédelmi műveinek felülvizsgált fejlesztési feladatairól, valamint a Tisza-völgy árvízi biztonságának növelésére vonatkozó koncepcióról (a Vásárhelyi-terv továbbfejlesztése) szóló 1022/2003. (III. 27.) Korm. határozatot. A jogszabályi háttér mögötti egyes koncepciók elemzéséről lásd: SzILÁGYI-DoBOs-Szűcs: i. m., 42-43.

${ }^{63}$ Lásd MTA 2019, MTA 2019; SzILÁGYI (2018): i. m., 123-128.

64 Lásd KJT 2017, 92.

${ }^{65}$ Lásd például BALOGH Péter: Árvízvédelem és gazdálkodás. In: Tóth Albert (szerk.): Tiszavölgyi tájváltozások, Kisújszállás, 2003, 127-142.; Somlyódy (szerk.): i. m.; UNGVÁRI Gábor-KIs András-RÁkosı Judit: Gazdaságszabályozási koncepció. Intézkedési javaslatok az ex-ante feltételek teljesítésére és az intézkedési program követelményei szerint rendszerezve A Duna-vízgyűjtő magyarországi része Vízgyűjtő-gazdálkodási Terv 2015, 8-5 melléklet, 2015; MTA 2019; etc.

66 KJT 2017, 92.

${ }^{67}$ Lásd például Somlyódy (szerk.): i. m.; TAMÁs János: Az aszály. Magyar Tudomány, 2017/10, $1228-1237$. (DOI: 10.1556/2065.178.2017.10.6). 
fog át ${ }^{68}$ - a Tisza esetében például az Alföld jelentős részét érinti a probléma (a pontos területi lehatárolás ugyanakkor ez esetben is nyitott kérdés még).

(g) A tájszemléletủ vízgazdálkodás megvalósíthatóságának fontos elemét képezik az annak elérését szolgáló intézkedések, eszközök, és az azokhoz kapcsolódó költségek meghatározása, ${ }^{69}$ mint amiként hasonlóan fontos a költségviselés kérdésének rendezése is. Találó gondolat ugyanakkor, hogy a megvalósítás költségeinek értelmezéséhez az is segít, ha megértjük a meg nem valósítás kárait. A költségek megosztásának időbeli tagolása, vagyis a fokozatosság elvének gyakorlati alkalmazása nagyban hozzájárulhatnak ahhoz, hogy azok a társadalom számára elfogadhatóbbak legyenek..$^{70}$

A fentiekre tekintettel a tájszemléletű vízgazdálkodás szempontjából a legérdekesebbek az öntözési törvény új intézményei közül az öntözésfejlesztési tervek és a környezeti körzeti tervek. Ezekröl a hidrogeológia, a talajtan és a jogtudomány szempontjából az alábbiakat tartjuk érdemesnek kiemelni. Előbb azonban e ponton is fontosnak tartjuk hangsúlyozni, hogy a jogalkotó az Ötvr.-rel egyelöre csak a környezeti körzeti tervek vonatkozásában fogadott el bizonyos részletszabályokat (illetve módosított más kormányrendeleteket, például a Khvr.-t) ${ }^{71}$ vagyis - különösen az öntözésfejlesztési tervek kapcsán - megállapításaink ennek fényében értékelendők.

\subsection{Az öntözésfejlesztési és környezeti körzeti tervek a rendelkezésre álló vízkészletek tükrében}

Az öntözési vízigények kielégítése a rendelkezésre álló vízkészletek figyelembevételével komplex vízgazdálkodási megközelítésen alapulhat csak. ${ }^{72} \mathrm{Az}$ uniós Vízkeretirányelven alapuló hazai vízgyüjtő-gazdálkodási terv (a továbbiakban: VGT 2) ${ }^{73}$ szemlélete alapján lehetséges csak az öntözési kerületekre vonatkozó öntözésfejlesztési tervek és az öntözési körzetekhez kapcsolódó, körzeti környezeti tervek elkészítése. ${ }^{74} \mathrm{Az}$ öntözési kerületek kijelölése az öntözési igazgatási szerv feladata. Ha megtörténik az öntözési kerület kijelölése, és elkészül a hozzá kapcsolódó öntözésfejlesztési terv, akkor ezen dokumentumokat kormányzati honlapon kell közzé-

${ }^{68}$ Lásd például A Tisza-mente integrált területfejlesztési, vidékfejlesztési és környezetgazdálkodási koncepciója. A koncepció az Országos Környezetvédelmi, Természetvédelmi és Vízügyi Főigazgatóság szerződése keretében a Magyar Terület- és Regionális Fejlesztési Hivatal és a Földművelésügyi és Vidékfejlesztési Minisztérium szakmai irányításával készült. A koncepciót a VÁTI Kht., az MTA RKK ATI és a VIZITERV Consult Kft. készítette. Budapest, 2004. májusi lezárású. Lásd továbbá KJT 2017.

69 UNGVÁRI-KIS-RÁKOSI: i. m. és MTA 2019.

70 HONTI Márk-SzILÁGYI János Ede-UNGVÁRI Gábor: Víztudományi program 6. fejezet - Társadalomtudományi kihívások: A vízszemléletü kormányzás - water governance. Gépirat, MTA Víztudományi Koordinációs Csoport, 2017. március 31. verzió.

71 Lásd különösen: Ötvr. 8. § (3), 14. §, valamint az Ötvr. 3., 4. és 5. mellékletei.

72 SzŰCs PÉTER: Felszín alatti vizek - a hidrológiai ciklus láthatatlan része. Magyar Tudomány, 2017/10. szám, 1184-1197. (DOI: 10.1556/2065.178.2017.10.2).

${ }^{73}$ Magyarország felülvizsgált, 2015. évi vízgyűjtő-gazdálkodási terve; a 1155/2016. Korm. határozattal elfogadva.

${ }^{74}$ A környezeti körzeti terv kapcsán az Ötvr. által módosított Khvr. fel is hív arra, hogy az ilyen terv „készítése és jóváhagyása során figyelembe kell venni a vízgyűjtő-gazdálkodási tervet is"; Khvr. 5/D § (4). 
tenni. A nagyobb léptékủ öntözési kerületek kijelölésének alapja egyértelműen a hazai vízgyüjtő-gazdálkodási tervben meghatározott 42 tervezési alegység (1. ábra) lehet, ahol az alegységi tervek vízmérlegeket is tartalmazó elkészítéséért a vízügyi igazgatóságok a felelősek. Az alegységi terv szintjén lehet azt meghatározni, hogy egy adott alegység vonatkozásában hány öntözési kerület jelölhető ki. Ez azt is jelenti, hogy az öntözésfejlesztési terveket elkészítö öntözési igazgatási szervnek szoros szakmai együttmüködést kell fenntartania a vízügyi igazgatóságokkal, hogy a felszíni és felszín alatti víztestek jó állapotát, valamint a fenntarthatósági aspektusokat a jövőben is garantálni lehessen. A vízügyi igazgatóságokon van meg az a szakmai kompetencia, amely alapján az öntözési célra felhasználható vizek menynyisége meghatározható az öntözési kerületek és a kisebb léptékű öntözési körzetek szintjén. Érdekes kérdést vet fel a vízigények priorizálása ${ }^{75}$ tekintetében az, hogy az öntözési fejlesztési terv és a környezeti körzeti terv a kiadástól számított 20 évig hatályos. Ezen tervek felülvizsgálata és módosítása lehetséges. Erre nagy valószínüséggel gyakran sort is kell majd keríteni, hiszen a vízügyi igazgatóságokhoz folyamatosan érkezhetnek újabb és újabb kommunális és ipari vízigények.

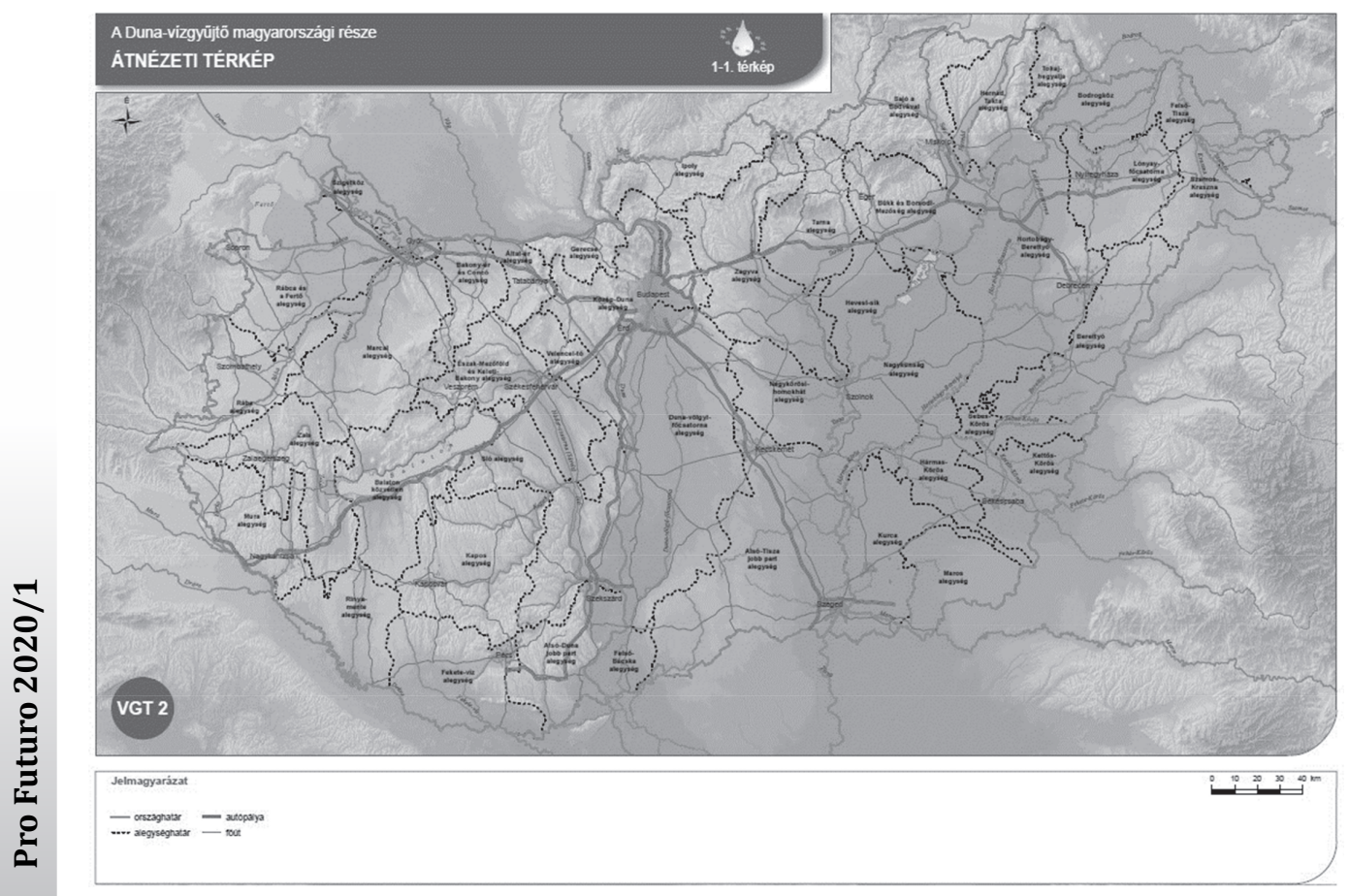

1. ábra. Vízgyüjtő-gazdálkodási tervezési alegységek Magyarországon a VGT 2 alapján

(Forrás: www.vizeink.hu)

${ }^{75}$ A Vgtv. szerint alapvetően a beérkezett igények időpontja határozza meg a vízigény-kielégítés sorrendjét, ha van szabad vízkészlet. Ha nincs elég készlet, akkor a priorizálás a vízkivétel célja alapján történik. 


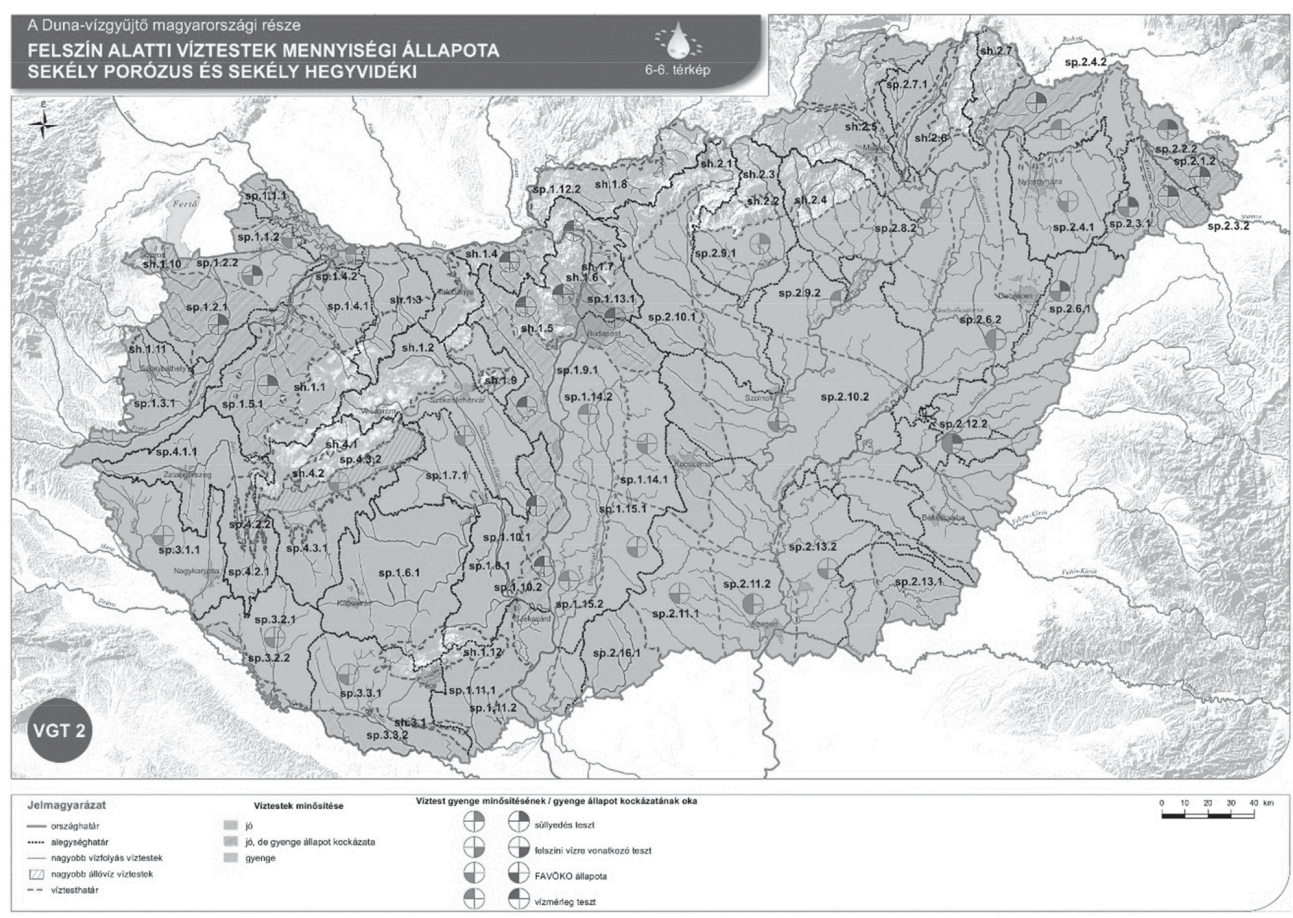

2. ábra. Felszín alatti víztestek mennyiségi állapota a VGT 2 alapján

(Forrás: www.vizeink.hu)

Különösen érdekes az öntözési vízigények kielégítésének a kérdésköre, ha figyelembe vesszük például a felszín alatti víztesteink állapotát, a várható öntözési igények szempontjából leginkább érintett területeket, a Tisza és a Körösök völgyében. ${ }^{76}$ Ezeken a területeken a sekély porózus víztestek jelentős kiterjedésben gyenge állapotot mutatnak a vízgyűjtő gazdálkodási terv alapján definiált mennyiségi aspektusokat illetően (lásd 2. ábra). Nem sokkal jobb a helyzet a sekély porózus víztestek minőségi vagy kémiai állapotát illetően sem. Ez egyben azt is jelenti, hogy az öntözés gyakorlati megvalósítása során jelentős mértékben tekintettel kell lenni a felszín alatti víztestek mennyiségi és minőségi állapotára, a mezőgazdasági és ökológiai előnyök mellett.

A jövőben negatív hatásokkal kell számolni az öntözési igényeket is kielégíthető szabad vízkészletek vonatkozásában a szélsőséges időjárási viszonyok egyre gyakoribb előfordulása miatt Magyarországon. Mindezek föleg a földi vízkörforgalom felszíni elemeire lehetnek hatással. ${ }^{77}$ Ugyanakkor a felszín alatti vizes monitoringhálózat

\footnotetext{
${ }^{76}$ SzÜcs PÉTER-KompÁR László-PALcsu László-DEÁK József: Estimation of groundwater replenishment change at a Hungarian recharge area. Carpathian Journal of Earth and Environmental Sciences, 2015/4, $227-246$.

77 BuDAY Tamás et al.: Sustainability aspects of thermal water production in the region of Hajdúszoboszló-Debrecen, Hungary. Environmental Earth Sciences, 2015/12, 7513-7521.
} 
segítségével ezeket a negatív hatásokat már a felszín alatti vizek esetében is egyértelmüen észlelni tudjuk. ${ }^{78}$

A mezőgazdasági célú öntözés volumenének növelésére leginkább a Duna-Tisza közi hátságon lenne szükség. A jelenlegi vízmérlegek adatai alapján megállapítható, hogy az öntözési vízigények kielégítése leginkább felszíni vízfolyásokból biztosítható hazánkban. Az intenzívebbé váló öntözés felszín alatti vizekre gyakorolt hatását leginkább hidrodinamikai és transzport modellezés segítségével tudnánk szemléltetni, amikor is különböző lehetséges szcenárió vizsgálatokkal elöre lehetne jelezni a várható mennyiségi és minőségi változásokat az érintett térségek felszín alatti vízkészleteiben, segítve ezzel is a tervezési és kivitelezési munkálatokat. A vízügyi monitoring adatokon alapuló modellezési szimulációk segíthetik a szakmai döntéselőkészítést az öntözési kerületek és az öntözési körzetek vonatkozásában. Az intenzívebb öntözést is magában foglaló vízgazdálkodás esetén még jobban megvalósítható a felszíni és felszín alatti vízkészletek együttes kezelése és hasznosítása. ${ }^{79}$

A Kemény Gáborék által készített, feltételezhetően az öntözésfejlesztési tervek és a körzeti környezeti tervek elkészítésénél fontos kiindulási alapot képező tanulmány ${ }^{80}$ az öntözés térbeliségére fókuszál, és elsősorban a termelő szempontjából közelíti meg az öntözhetőség összetett problémakörét. Az öntözhető növények által lefedett, nem öntözött területből kiindulva végezték el a mezőgazdaság szabadföldi öntözési vízigényének becslését. Helyesen állapítja meg a tanulmány a realitásokra támaszkodva, hogy hazánkban a mezőgazdasági vízigény nagyobb részét felszíni vízből kell biztosítani. Erre tekintettel tekinthető a tanulmány egyik fő eredményének az öntözésfejlesztéssel kapcsolatos azon megállapítása, hogy felszíni vízből 409 millió $\mathrm{m}^{3}$, míg a felszín alatti vízkészletekből 98,9 millió $\mathrm{m}^{3}$, vagyis együttesen 507,9 millió $\mathrm{m}^{3}$ vízigény biztosítható. Adataik alapulvételével a jelenlegi, mintegy 51 ezer hektár, ${ }^{81}$ felszíni vízkészletekből öntözött szabadföldi mezőgazdasági területet 337,2 ezer hektárral lehetne bővíteni, míg a már most is felszín alatti vízkészletekből öntözött 3 ezer hektár területet nagyságrendileg 45 ezer hektárral lehetne növelni. Ezeket az öntözhetőségi számokat Kemény Gáborék leginkább arra a stratégiai dokumentumra alapozzák, amelyet a hazai vízgazdálkodás jövőjét illetően Somlyódy Lászlóék ${ }^{82}$ készítettek. A hivatkozott dokumentum arra nem tér ki ugyan, hogy a közel 100 millió $\mathrm{m}^{3}$ nagyságú évi öntözési célú felszín alatti vízmennyiséget hol és hogyan, valamint milyen konkrét felszín alatti víztestekből lehetne biztosítani, ugyanakkor azt rögzíti, hogy az Alföld vonatkozásában nincs szabad felszín alatti vízkészlet. Az ön-

\footnotetext{
78 PAlcsu László-KompáR László-DeÁK József-Szűcs Péter-PAPp László (2017): Estimation of the natural groundwater recharge using tritium-peak and tritium/helium-3 dating techniques in Hungary. Geochemical Journal, 2017/5, 439-448.

79 PETITTA, Marco et al. (2018): The KINDRA project: sharing and evaluating groundwater research and knowledge in Europe. Acque Sotterranee - Italian Journal of Groundwater, AS24-324, 07-16. (DOI: 10.7343/as2018-324).

${ }^{80}$ Kemény Gábor-Lámfalusi Ibolya-Molnár András (szerk.): Az öntözhetőség természeti-gazdasági korlátainak hatása az öntözhető területekre. Agrárgazdasági Kutató Intézet, Budapest, 2018 (DOI: http://dx.doi.org/ 10.7896/ak1801).

${ }^{81}$ Az adat a Kemény-Lámfalusi-Molnár (szerk.): i. m.-ben szerepel; az Agrárminisztérium 2020. májusi közleménye alapján ez jelenleg 87,5 ezer hektár. Lásd erről az Agrárminisztérium Sajtóirodájának már idézett közleményét.

82 Somlyódy (szerk.): i. m.
} 
tözési törvény által meghatározott öntözési kerületek és öntözési körzetek kapcsán is regionális és lokális, akár tábla szintű hidrodinamikai és transzportmodellezési vizsgálatok segíthetik a vízgazdálkodási célú döntés-előkészítést és a szükséges hatásvizsgálatokat. ${ }^{83} \mathrm{Az}$ Ötvr. rendelkezései egyértelmű szakmai útmutatást adnak a környezeti körzeti terv elkészítését és jóváhagyását illetően. Az öntözési igazgatási szerv az öntözni kívánt területre vonatkozó, környezeti körzeti tervet nyújt be a környezetvédelmi hatóságnak jóváhagyás céljából. Az Ötvr. útmutatásai alapján a környezetvédelmi hatóság előzetes vizsgálatot vagy környezeti hatásvizsgálati eljárást folytat le. Szakmai szempontból fontos követelmény, amit az Ötvr. is megerősít, hogy a környezeti körzeti terv készítése és jóváhagyása során figyelembe kell venni a vízgyűjtő-gazdálkodási tervet.

\subsection{Az öntözésfejlesztési és környezeti körzeti tervek a talajtan tükrében}

Az öntözés talajtani összetevőinek, veszélyeinek és jó gyakorlatainak igen gazdag hazai irodalma van, számos jó szakkönyvvel. ${ }^{84}$

Az öntözési törvény számos ponton kiemeli a talajtani, vízföldtani, domborzati és a vízrajzi viszonyok messzemenő figyelembevételének igényét az öntözési kerületek kijelölésénél, illetve az öntözési kerületre vonatkozó öntözésfejlesztési tervek elkészítésénél. A tervezési egységet a vízgyűjtő gazdálkodási alegységek alapján meghatározott öntözési körzetek jelentik. Ezek öntözési szempontból egységesnek vagy vízgazdálkodási szempontból összetartozónak vélt területek lehatárolásával jönnek létre, amelyen belül a talajtani, vízföldtani, domborzati és a vízrajzi viszonyok egységesen, az adott területre vonatkozó öntözésfejlesztési tervek irányelvei szerint kezelhetők. Ebből a szempontból a törvény a vízgazdálkodást optimalizáló és talajvédelmet, klímavédelmet és biodiverzitást kiemelten kezelő VTT elveit követi.

\subsubsection{Tájhasználat-optimalizálás, a vízgazdálkodási problémák egységes rendszerben való kezelésének igénye}

A VTT egyik alapvető elemét, a tájhasználat-optimalizálást sem a törvény, sem az Ötvr. semmilyen szinten nem kezeli. Az Ötvr. csak az öntözésbe vonandó táblára, illetve a körzetek esetén a közbeékelödött táblákra koncentrál, a környező területeket nem vizsgálja. Történik ez annak ellenére, hogy a törvény megfogalmazza a domborzati, talajtani, hidrológiai szempontok szerint egyben kezelendö öntözési kerületek rendszerét, melyek vízgazdálkodási szempontból összefüggő, és csak egységes rendszerben kezelhető területek.

\footnotetext{
${ }^{83}$ Megjegyezzük, hogy habár az Ötv. konkrétan nem írja elő mindezeket, de mindenképpen lehetővé teszik: az Ötvr. 14. §-ával a Khvr.-be beiktatott új 5/D. § (3) bekezdése utal a Khvr. 4. és 6. mellékletére is. A4. melléklet 1. f. ff) alpontja, ill. a 6. melléklet 4.a. ah) pontjában előírt hatásbecslés a felszín alatti vizeknél másképp nem nagyon lehetséges, föként, ha a védett területekre történő hatást kell kimutatni.

${ }^{84}$ Lásd különösen DARAB Katalin-FERENCz Kálmán: Öntözött területek talajtérképezése. Országos Mezőgazdasági Minőségvizsgáló Intézet, Budapest, 1969; Stefanovits Pál (szerk.): Talajvédelem, környezetvédelem. Mezőgazda Kiadó, Budapest, 1977; DöMsöDı János: Talajjavítási útmutató. Mezőgazda Kiadó, Budapest, 1984.
} 
Az öntözés a vízgazdálkodási problémák egy viszonylag kis részét érinti, a szárazság okozta gazdasági, ökológiai hatásokra koncentrálva. Az aszályhelyzetek jelentős része nem csak klimatikus okokból alakul ki, számos talajtani, vízgazdálkodási öszszetevője van, melyeket egységesen kellene kezelni ${ }^{85} \mathrm{Az}$ aszályos területek gyakran belvizesek is, illetve áradások is sújthatják azokat. E három probléma önmagában való megoldása más és más beavatkozásokat, megközelítést igényel, a vízgazdálkodási problémákat csak komplexen, egy rendszeren belül lehet kezelni. A belvizek elvezetése a talajvíz csökkenésével jár, ami „kihúzza” a magasabban fekvő táblák alól a vizet. Az elvezetett, kiszivattyúzott víz nagyon hiányzik a szélsőségesedő klímafeltételek között. A célterületek alluviális, folyóvízi üledékanyagai és formakincse máig meghatározza a termelési és vízgazdálkodási viszonyokat, megőrizve a hajdani táj jellegzetességeit. A mélyebb fekvésü öntés és réti talajokon, illetve a feltöltődött medermaradványok mikromélyedéseiben szinte minden tavasszal megjelenik a víz, ami nagyban rontja a termelési feltételeket.

Az öntözéssel szintén jelentősen befolyásoljuk a talajnedvesség-gazdálkodást, emeljük az ezzel összefüggő talajvízszintet, ami a mélyebben fekvő területeken okozhat gondot. Látható, hogy a problémák külön-külön való kezelése nem oldja meg a vízgazdálkodási nehézségeket. Az optimális megoldásoknak legalább részben érinteniük kell a talajtani és domborzati adottságok alapján történő tájhasználati optimalizálást. A VTT-ben is megjelenő tájrehabilitációs elképzelések jelenthetik a komplex megoldás alapját, melyekre sem a törvény, sem az Ötvr. nem tér ki.

$A z$ is ismert, hogy sem az öntözés, sem a belvízelvezetés hatásai nem lokálisak, sokszor érezhető hatást gyakorolnak a környező területek vízgazdálkodására, termelési viszonyaira is. Különösen igaz ez akkor, ha figyelembe vesszük a felszín alatti, eltemetett mederrendszerek hatását, illetve az eltérő textúrájú hordalékanyagokon képződött talajokat, melyek teljesen eltérő módon reagálnak a vízgazdálkodási megoldásokra.

\subsubsection{A kerületek és körzetek kialakitásának talajtani szakmaspecifikus elemei}

Az öntözési törvény kerületeinek és körzeteinek egységes talajtani, vízföldtani, domborzati és vízrajzi viszonyok alapján történő kialakítása egy jó keretrendszert jelent, de természetesen csak abban az esetben, ha a szakhatóságok jelentős erövel rendelkezhetnek a területek lehatárolásánál. Míg a törvény rendelkezik az öntözési infrastruktúra kialakítását segítő tulajdonjogi, szolgalmi kötelezettségekröl, a tájhasználat optimalizálását segítő jogi eszközöket nem vet fel, pedig ezek nélkül a komplex szemléletmód nem tud és nem is fog megjelenni az eredmények között. Ennek hiányában nem látszanak a kerületek lehatárolását meghatározó irányelvek sem.

85 Természetesen itt joggal vethető fel, hogy e problémakört a vízgyűjtő-gazdálkodási tervben is lehetne kezelni, a mezőgazdaságot (is) érintő (feladatkörébe eső) intézkedések tervezésével és végrehajtásával (például földhasználatváltással, szárazságtűrő növények termesztésével, hatékony vízhasználattal). A vízkormányzáson túl a szélsőségek kezelésére vannak gazdasági ösztönzők is (például a Közös Agrárpolitika vidékfejlesztési támogatásai). 
Az öntözési körzetek kialakításánál szükség lehet az öntözött területek és a környezetükben található, velük egy talajtársulást, vízgazdálkodási egységet képező táblák talajtani alapú területhasználati optimalizálására, ami jogi szempontból nagyon nehéz feladat. Földterületek cseréjét, illetve müvelési módjának részleges vagy teljes megváltozását igényelheti a hatékony, kompromisszummentes körzetesítés. A törvény az öntözési körzetek kialakításánál az öntözési közösségek által öntözni kívánt táblák külső határait összekötő poligont veszi figyelembe, így a körzet részei az öntözött, illetve az öntözött táblák közé ékelödött táblák. Az öntözés hatásait a körzettel közvetlenül érintkező területeken nem vizsgálja, pedig az öntözés és a vízhasználat ezen területek vízforgalmára és talajaira is jelentős hatást gyakorol. Nem beszélve arról, hogy privilegizálja a létrehozott közösség tagjait a „szomszédokkal” szemben, mert az adott vízkészlet-felhasználást is közösségre számítja és osztja el, míg a később belépő, ugyanarra a víztestre és vízgazdálkodási egységre települő gazdák már eleve hátrányból indulnak. Ezt a problémát csak részben kezelné a kerületek kialakítása és az öntözés kerületen belüli környezeti hatásainak előzetes, átfogó vizsgálata. A körzetek területeit, de legalábbis az Ötvr.-ben előírt és részletezett környezeti körzeti tervek területi határait az öntözés potenciális hatásterületeire is ki kell terjeszteni.

\subsubsection{A talajerőforrások védelme}

Az infrastruktúra kiépítésénél is figyelembe veendő tényező a talajadottságok köre. Értékelendő cél a beruházásokkal érintett terület minimalizálása, de talán hatékonyabb és hosszabb távon gazdaságosabb a talajtani adottságokhoz is illesztett infrastruktúra-fejlesztés. Célszerü lenne a gyengébb adottságú, nehezebben művelhető területek kivonása a múvelésböl a fejlesztések érdekében, elkerülve a jó adottságú területek beépítését. Ennek egyik eszköze a minőséget jelző - bár erősen elavult aranykorona-érték rendszer figyelembevétele, amit az Ötvr. meg is tesz az öntözési szolgalom keletkezésével kapcsolatos, egyszeri kártalanítás szabályozásakor. A rendelet által meghatározott, 50000 forint aranykoronánként és hektáronkénti kártalanítási összeg (Ötvr. 1. melléklet) viszont nagyon alacsony, a felét sem éri el a területek piaci értékének, így mégsem tudja hatékonyan kifejteni talajvédelmi hatását. Arról nem is beszélve, hogy a rendelet a terület átlagos aranykorona-értékét veszi alapul, ami nehezen értelmezhető és vitákra adhat alapot, miközben a kivont területek tényleges aranykorona-értéke és területe alapján is számítható lenne az érték.

\subsubsection{A talajvédelmet megalapozó talajtani alapállapot-felmérés kötelező igénye}

A fentiek alapján megállapítható, hogy a körzetek lehatárolása és a körzetek öntözési lehetőségeit meghatározó öntözésfejlesztési tervek tartalmi követelményei meghatározóak. Fontos kérdés, hogy a tervek, illetve a támogató dokumentációk milyen szinten fogják leírni a területen belüli talajtani változatosságot, lesznek-e térképi megjelenítések, zónalehatárolások, illetve ha igen, akkor milyen méretarányban készülnek majd el. Nem várható el a tervet készítő hatóságtól a területek nagy 
felbontású térképezése. A kerületek szintjén elkészülő térképi állományoknak a talajtani, mikrodomborzati változatosság-trendjeit kell a kerületeken belüli zónákra meghatározni. Ez jelentheti típusterületek mintatérképezését és az adott jellegzetességgel bíró változatosságot fenntartható módon kezelő komplex vízgazdálkodási megoldások megfogalmazását, illetve hidrodinamikai és transzportmodellezést a kerületeken belül.

Nagy belső változatosság esetén viszont elkerülhetetlen a részletes talajtani térképezés, illetve a változatossághoz illeszkedő, precíziós öntözési megoldások alkalmazásának megkövetelése. ${ }^{86}$ Talajtani, talajvédelmi és középtávú gazdaságossági szempontok alapján is kötelezővé kellene tenni az öntözésmenedzsment-zóna tervének elkészítését, illetve nagy változatosság esetén a precíziós gazdálkodási irányelvek figyelembevételét és kötelező alkalmazását. Ezt nemcsak a talaj- és vízvédelmi igények támasztják alá, hanem a befektetett erőforrások és felhasznált öntözővízmennyiség optimális hasznosulása is.

Az Ötvr. által módosított Khvr. a körzetek szintjén, pontosabban az öntözni kívánt területek szintjén erre konkrét utalást is tesz. A területek a Khvr. 5/D. §-ában, illetve a Khvr. 14. mellékletében meghatározott tartalmú vizsgálatánál átemeli a korábbi öntözésfejlesztéseknél elvárt talajvédelmi tervek tartalmi elemeit. Ezen túlmenően meghatározza a mintavételi sürüséget, az öntözés esetén minden eltérő talajfoltra, de legalább 25 hektáronkénti értékkel. Ezt természetesen meg kell, hogy előzze egy részletes talajfelvételezés, amit az Ötvr. is elvár, és az 1:10 000 méretarányú talajtérképet kötelező tartalmi elemként határozza meg. Ilyen térképek készültek az 1970-es és 1980-as években, az úgynevezett üzemi genetikus térképek formájában. Ezek csak a nagyüzemi gazdaságok területére készültek el, és azok közül is igen sok elveszett, illetve a még meglévők is papír alapon léteznek, módszertanukban elavultnak mondhatók. Nem a jelenlegi digitális talajtérképezési technológia eszközeivel, alapvetően sokkal kisebb felbontásban, és nem is a mai öntözési technológia igényei szerint készültek el. Javasolt új, specifikusan öntözési célú térképek készítése, illetve az üzemi genetikus térképek digitális és tartalmi felújítása. Hasonlóképpen elavult a szintvonalas térképvázlat kifejezés a humuszos termőréteg-vastagságról. A precíziós technológia már többnyire raszteres, folytonos állományokat igényel. Mindenképpen javasolt az adatok térinformatikai rendszerben és formátumban történő elkészítése, ami az agrárdigitalizációt is érintő, jelentős és szakmailag szinte kötelező elörelépés.

Az Ötvr. által módosított Khvr.-ben meghatározott paraméterek helytállóak, a szakmai igényeket lefedik. A Khvr. új 14. melléklete kitér a talajvédelmi specifikációkra, ami fontos elem, de csak az eróziót, és érdekes módon a mélylazítást taglalja, a vízháztartási viszonyok tartós megváltozása, a szerkezeti degradáció elkerülése, illetve a szikesedés nem említődik, pedig ezek talán a legfontosabb, öntözés okozta talajdegradációs folyamatok. Teszi ezt annak ellenére, hogy az adatokat „sóforgalmi számítások" cím alatt részben megkéri hozzá. Ezen kívül nagy hangsúlyt kap a hu-

${ }^{86}$ JaKAB Gergely-Dobos Endre-Madarász Balázs-Szalal Zoltán-Szabó Judit Alexandra: Spatial and Temporal Changes in Infiltration and Aggregate Stability: A Case Study of a Subhumid Irrigated Cropland. Water, 2019/5, 876-888. (DOI: 10.3390/w11050876). 
muszmentés kérdésköre, ami elsősorban az építési munkálatokban képződött feltalaj deponálását, elhelyezését szabályozza, ami a jelenlegi humuszmentési tervek készítésének gyakorlatát emeli át az Ötvr.-be. ${ }^{87}$

\subsubsection{Szabályozási irányból fakadó nehézségek}

Az általánostól a specifikus irányában, a rendszer ismerete nélkül nem lehet annak elemeit szabályozni. A körzetek meghatározásánál a törvény kicsit technokrata módon gondolkodik, elsősorban az öntözési rendszerre rácsatlakozó, és öntözéses gazdálkodást folytató gazdák területeire koncentrál, ami szervezési és irányítási szempontból nyilvánvalóan célszerü. Ezzel azonban teljesen háttérbe kerül a komplex vízgyűjtő gazdálkodási irányelv. Ez akkor válik meghatározóvá, ha az öntözési szövetkezet hamarabb alakul meg, mint ahogy az öntözésfejlesztési terv elkészülne. Ebben az esetben a törvény lehetőséget ad környezeti körzeti terv készítésére, ami hasonló tartalommal bír, mint az öntözésfejlesztési terv, de csak a kerület egy kis részét érinti, így nem képes a nagyobb, vízgyűjtő szintű tervezésre és optimalizálásra. Ez így ellentmondás, és kényszerpályára állíthatja az öntözésfejlesztési tervet.

A törvény jelenleg nem rendelkezik a szakmai felügyeletröl, hogy milyen szinten és mely szervek fogják vizsgálni a kivitelezés esetén a terveknek és az irányelveknek való megfelelést. Talajtani szempontból ez nagyon szakemberigényes, specifikus terület.

\subsubsection{Talaj- és vízmonitoring, a környezeti adatok megosztásának igénye}

Sarkalatos kérdés az Ötv. 6. § (4) pontjában meghatározott 20 éves hatályossági időtartam is. Az öntözés gazdasági haszna mellett nagyon nagy talajdegradációs veszélyt hordoz. A nem megfelelő öntözés talajtani hatásai már rövid idő alatt jelentkeznek, 20 év alatt visszafordíthatatlan károkat okozhatnak, melyek nemzetgazdasági értelemben is jelentősek lehetnek. Szakmai szempontból megkerülhetetlen a kötelező talaj- és vízmonitoring-rendszer kiépítése, és az ebből származó adatok megbízható módon történő megosztása a hatósággal. ${ }^{88}$ Ennek részét képezheti a kötelezően végrehajtott, időszakos talajtani vizsgálatok adatainak megosztása és központi ellenőriztetése, de bizonyos esetekben szükség lehet célirányos monitoringrendszerek telepítésére, a körzeten belüli változások követésére. Ez az igény egyébként a 6 . § (6) pontban is megjelenik, az öntözésfejlesztési tervek rendszeres felülvizsgálata kapcsán, ugyanakkor az Ötvr.-ben egyelőre egyáltalán nem jelenik meg.

A 13. § érinti a szakadatok körét. Az öntözési adatgyüjtés és szolgáltatás körének ki kellene terjednie a monitoringfeladatok elvégzéséhez szükséges termelési, illetve az időszakosan elvégzendő talajtani vizsgálatok adataira, melyek beszolgáltatását

\footnotetext{
${ }^{87}$ Lásd: 90/2008. (VII. 18.) FVM rendelet a talajvédelmi terv készítésének részletes szabályairól.

${ }^{88}$ Ez nem része az előírásoknak itt ugyanis a gazdálkodóra plusz terhet róna. Egyelőre csak abban lehet bízni, hogy a gazdálkodók maguk ismerik fel, hogy az ő érdeküket is szolgálná a megfelelő monitoring. Ugyanakkor a felszín alatti vizeknél monitoringlehetőséget vízkészlet-gazdálkodási mennyiségi szempontból a 147/2010. kormányrendelet 60 . $§(6)$ bekezdése ír elő.
} 
a szakmai felügyelet megteremtése érdekében kötelezővé kellene tenni. Ehhez a ponthoz tartozik az adatokhoz hozzáférők körének meghatározása is. A 14. § (2. b) pontban meghatározott adathozzáféréssel bíró szervek esetén is érdemes lenne a kör bővítése. Mivel az öntözés tartós negatív környezeti hatást gyakorolhat a vízminőségre, a vízkészletek változására és a talajtani adottságokra, itt szükséges lenne a hozzáférést kapó intézmények körének kiszélesítése, a talajtani kutatásokkal foglalkozó kutatóintézetek, egyetemek és civil szervezetek valamilyen szintü feljogosítása is akár.

\subsection{Az öntözésfejlesztési és környezeti körzeti tervek a jogtudomány tükrében}

A jogtudományi szempontrendszer bemutatásának elején ki kell emelni azt, hogy az öntözési törvény elfogadásával még nem ért véget a jogalkotási folyamat, $s$ az Ötvr. is lényegében csak az öntözési körzetekre, illetve az azokhoz kapcsolódó környezeti körzeti tervekre vonatkozó részletszabályokat állapítja meg; az öntözési kerületek kialakításáról és a kapcsolódó öntözésfejlesztési tervek részletszabályairól egyelöre hallgat. Logikusan feltételezhetjük, hogy később e részletszabályok is elfogadásra kerülnek, ugyanis ezek nélkül az öntözési kerületek és az öntözésfejlesztési tervek törvényi szabályai aligha lennének érdemben végrehajthatók. Mindezekre tekintettel jelen alfejezetben leginkább a még hátralévő jogalkotás és az elfogadásra váró öntözésfejlesztési tervek elkészítése során figyelembe veendő szempontokra hívjuk fel a figyelmet.

E szempontok kapcsán természetesen megannyi jogi feltétel jöhetne számításba, magunk a tájszemléletű vízgazdálkodáshoz különösen közel állók közül a következőket emelnénk ki. Egyrészt a Víz-keretirányelvnek a vizek jó állapotára vonatkozó, egyébiránt számos vonatkozásban nehezen értelmezhető és teljesíthető ${ }^{89}$ követelményét, másrészt pedig az Alaptörvény, különösen annak XX., XXI. és $P$. cikkéből levezetett, az alkotmánybírósági joggyakorlat által kifejlesztett visszalépés tilalmát, ${ }^{90}$ illetve az elővigyázatosság elvét. ${ }^{91}$

Utóbbi, alkotmányos szempontrendszer kapcsán előzetesen fontosnak tartjuk kiemelni a jövő nemzedékek szószólójának (a továbbiakban: szószóló) az Ötv. tör-

${ }^{89}$ Ennek jelentős nemzetközi és magyar szakirodalma van; a teljesség igénye nélkül utalnánk csak a következő magyar szerzők munkáira: SzILÁGYI (2018): i. m., 184-189.; BARANYAI Gábor: European Water Law and Hydropolitics. Springer, Cham, 2020, 98-100. (DOI: https://doi.org/10.1007/978-3-030-22541-4).

90 Ennek jelentős magyar szakirodalma van; a teljesség igénye nélkül utalnánk csak a következőkre: FoDOR László: Környezetvédelem az alkotmányban. Gondolat - Debreceni Egyetem ÁJK, Budapest, 2006, 50-56.; BÁNDI Gyula: Környezeti értékek, valamint a visszalépés tilalmának értelmezése. Iustum Aequum Salutare, 2017/2, 159-181.; BÁNDı Gyula: A visszalépés tilalma és a környezetvédelem. In: Gellén Klára (szerk.): Honori et virtuti. lurisperitus, Szeged, 2017, 9-23.

${ }^{91}$ Ennek jelentős nemzetközi és magyar szakirodalma van; a teljesség igénye nélkül utalnánk csak a következő magyar szerzők munkáira: BÁNDı Gyula: Gondolatok az elővigyázatosság elvéről. Jogtudományi Közlöny, 2013/10, 471-480; FodoR László: A precíziós genomszerkesztés mezőgazdasági alkalmazásának szabályozási alapkérdései és az elővigyázatosság elve. Pro Futuro, 2018/2, 42-64.; HoRvÁTH Zsuzsa: Védelem a tudományos bizonyosság hiányában. In: Csapó Zsuzsa (szerk.): Ünnepi tanulmánykötet Bruhács János professor emeritus 70. születésnapjára. PTE ÁJK, Pécs, 2009, 88-115. 
vényjavaslatához füzött, alkotmányossági aggályairól szóló figyelemfelhívását. ${ }^{92}$ A figyelemfelhívás az Ötv.-javaslat több jogintézményével is foglalkozott. Érdemes kiemelni azt, hogy a szószóló figyelemfelhívása az Ötv. törvényjavaslatára válaszul született, s hogy végül a törvényszöveget, a szószóló által elemzett részeket érintöen is jelentős módosításokkal fogadták el. Jelen részben csak az öntözésfejlesztési tervekkel, illetve a környezeti körzeti tervekkel kapcsolatos megállapításokkal foglalkozunk, azok közül is elsődlegesen azokra fókuszálunk, amelyek meglátásunk szerint is elgondolkodtató megfontolásokat tartalmaznak. A figyelemfelhívás sommás megállapítása a tervekkel kapcsolatban az volt, hogy a számos engedélyt felváltani hivatott öntözésfejlesztési terv, illetve környezeti körzeti terv csak akkor nem ütközik a visszalépés tilalmába, ha az új jogintézmények (vagyis a tervek) hasonló hatékonysággal képesek védeni a nemzet, Alaptörvényben védett, közös örökségét. ${ }^{93} \mathrm{Itt}$ ismételten utalnunk kell arra, hogy a tervet előzetesen a környezetvédelmi hatóság „érvényesíti”, és ezt követően minősül (környezetvédelmi) engedélynek vagy szakhatósági állásfoglalásnak (küszöb alatti hatásnál). Tehát valójában nem maga, illetve nem pusztán a terv minősül engedélynek vagy szakhatósági állásfoglalásnak. A szószóló szerint a hatósági engedély helyett bevezetett, az igazgatási szerv által megalkotott terv már a formája miatt sem alkalmas a jelenlegivel azonos szintủ védelem biztosítására. ${ }^{94} \mathrm{~A}$ szószóló aggályosnak véli a tisztességes eljáráshoz és a jogorvoslathoz való jog szempontjából azt is, hogy a „döntéssel érintett szereplők - ideértve a környezetet, illetve a természetet, mint a terhelést passzívan elviselöket képviselöket is - nem tudnak az eljárásban részt venni, érdekeiket megjeleníteni és érvényesíteni” ${ }^{95} \mathrm{~A}$ szószóló - több más mellett - sérelmezi az Ötv.-javaslatban szereplő tervek időbeli hatályának terjedelmét is (a törvényjavaslatban még 15 év szerepelt):

szükségesnek tartom arra is felhívni a figyelmet, hogy az öntözésfejlesztési terv 15 évig hatályos függetlenül attól, hogy a különböző engedélyezési eljárások során milyen feltételek teljesülése mellett, milyen időtávra lehetne az engedélyeket kiadni. Hangsúlyozandónak tartom, hogy a közösség érdekében meglévő eljárási garanciákat - mint amilyen az engedélyek időtartamának hossza -, nem írhatnák felül az egyéni érdekek. A javaslat szerint az öntözés közérdek. Ez azonban nem indokolja az Alaptörvényböl fakadó garanciák csökkentését, megszüntetését, s ezáltal a jogszabályokban biztosított védelmi szint csökkentését. ${ }^{96}$

A szószóló problematikusnak tekinti továbbá azt, hogy a különböző tervek elfogadásában az igazgatási szerv mintegy a beruházók képviselőjeként jár el:

A visszalépés tilalma szempontjából is aggályos és a jogbiztonság sérelmét is felveti az a rendelkezés, mely az öntözési igazgatási szervre azt a feladatot rója, hogy

\footnotetext{
${ }^{92}$ A jövő nemzedékek szószólójának figyelemfelhívása az öntözéses gazdálkodásról szóló T/7845 törvényjavaslattal kapcsolatos alkotmányossági aggályokról. Jövő nemzedékek érdekeinek védelmét ellátó biztoshelyettes, 2019. november 12., AJB-5469-1/2019. ügyszám.

${ }_{93}$ AJB-5469-1/2019. figyelemfelhívás, 1. pont.

${ }_{94}$ AJB-5469-1/2019. figyelemfelhívás, 1. pont.

95 AJB-5469-1/2019. figyelemfelhívás, 1. pont.

${ }^{96}$ AJB-5469-1/2019. figyelemfelhívás, 1. pont.
} 
megbízás alapján az öntözési beruházást kezdeményező mezőgazdasági termelőt a vízjogi eljárásban képviselje [...]. Ez azt jelentené, hogy a hatósági határozatokat felváltó öntözésfejlesztési terv készítője az ügyfél megbízottjának szerepét foglalja el az öntözés lényegéről, a vízilétesítmény létesítéséről szóló vízügyi engedélyezési eljárásban, azaz az öntözésre vonatkozó magatartások meghatározásában részt vevő szereplő pozíciójában jelentős romlás következik be, mert a hatóság helyett, az ügyfél megbízottjává válik. Ez a pozícióváltás komoly visszalépés a jelenleg hatályos szabályozáshoz képest, és az állami szereplő ellentmondásos szerepe jogbiztonsági kérdéseket is felvet. ${ }^{97}$

A szószóló értékelésében lényegében az Alkotmánybíróság által nemrég kifejlesztett elővigyázatosság elvére történő utalást találunk, amikor a szószóló felhívja a figyelmet arra, hogy a „garanciális jogintézmények megváltoztatása esetén a jogalkotó kötelezettsége, jelen esetben a javaslat elöterjesztőjének feladata annak bizonyítása, hogy a védelmi szintben nem következett be visszalépés". ${ }^{98}$

Meglátásunk szerint is az új szabályozás egyik központi kérdése, hogy az egyedi környezetvédelmi, illetve természetvédelmi engedélyek kiváltása az öntözésfejlesztési tervekkel és körzeti környezeti tervekkel nem sérti-e mintegy jogintézményi szinten a visszalépés tilalmának elvét. Meglátásunk szerint az öntözés infrastruktúrájának nagyobb rendszerben történő értékelése éppen a környezetvédelem integratív szemléletének egyik megvalósulásának garanciája is lehet, vagyis ez esetben éppen fejlesztöleg is hathat a környezet állapotára. Ugyanakkor, amennyiben a területi lehatárolások eredményeként a döntéshozók az egyes tervekben nem nyújtanak garanciát az egyedi szempontok megfelelő kezelésére (például egyfajta fünyíróelv alkalmazásával), akkor viszont a jogintézmény a visszalépés tilalmának sérelméhez vezethet. Meglátásunk szerint e vonatkozásban sok múlik a részletszabályok kialakításán, és a törvényi, illetve rendeleti szabályok együttes értelmezésével juthatunk csak el a szabályozás korrekt értékeléséhez a visszalépés tilalma szempontjából. E vonatkozásban nem segíti a megfelelő következtetések levonását, hogy az öntözési kerületekre, illetve öntözésfejlesztési tervekre vonatkozó részletszabályok továbbra sem készültek el.

Az egyes öntözésfejlesztési tervek - és azokon belül a körzeti környezeti tervek által lefedett területek lehatárolásánál kiindulási alapként a magyar vízgyüjtő gazdálkodási terv 42 tervezési alegységéből javasolnánk kiindulni, majd ezt követően lehetne a többi szempont, így például a talajtani szerint is tovább részletezni a területeket.

Az egyes öntözésfejlesztési tervek és körzeti környezeti tervek által lefedett területeknek optimális esetben minden releváns szempontból egységesnek kellene lenniük a hozzájuk tartozó területek vonatkozásában. A területi lehatárolások során erre törekedni kell, ugyanakkor a figyelembe veendő szempontok nagy száma miatt bizonyos - például jelen tanulmány vízgazdálkodási, illetve talajtani részében részletezett - környezeti szempontokból várhatóan - eltérő mértékben, de - nem lesznek egységesek. Meglátásunk szerint ugyanakkor ettől még a tervek alkalmasak lehetnek a tanulmányunk által képviselt célok megvalósítására, azonban mindez csak

${ }^{97}$ AJB-5469-1/2019. figyelemfelhívás, 3. pont.

${ }^{98}$ AJB-5469-1/2019. figyelemfelhívás, 5. pont. 
akkor valósulhat meg, ha az adott területen belüli egyedi részeknél egyedi módon értékelik a fenntarthatósági szempontok dimenziót, és erre (is) tekintettel, az egyedi részek sajátosságait is tiszteletben tartva határozzák meg az adott területi egységen alkalmazható öntözési megoldások körét. Például adott esetben elvárt lehet a fentebb már említett, akár táblaszintű talajtani, hidrodinamikai és transzportmodellezési vizsgálat. Mivel a hidrodinamikai rendszerek vizsgálata inkább a vízgyűjtő szintjén kivitelezhető, míg táblaszinten az ezeket nagyon jól jellemző talajtani vizsgálatok jelenthetik a leghatékonyabb megközelítést, ezért a tervezési szintek eltérő szakmai megvalósítási prioritásokat jelentenek. A körzetek kialakításánál a hidrodinamikai, transzportmodellezési jellemzők a meghatározók, amelyek lokális hatásai a talajtársulások milyenségében manifesztálódnak, ezért a körzetek lehatárolásánál a hidrodinamikai jellemzőket kell a törvényalkotásnál kiemelni, míg a konkrét megvalósulási helyszíneket jelentő társulások esetén a talajtani, mikrodomborzati és tájhasználati adottságok lesznek meghatározók, így ezek nagyléptékű vizsgálata, feltérképezése az öntözési zónarendszer kialakításánál elengedhetetlen a fenntarthatóság és a természeti erőforrások védelme szempontjából. Ezek az elvek részben megjelennek az Ötvr.-ben, de csak a táblaszintü vizsgálatok kapcsán. Térbeli összefüggések és rendszerszintü elemzési igény a körzetek szintjén nem jelenik meg és nem is tud megjelenni, mert csak az öntözés területére koncentrál, a szomszédos, funkcionálisan összefüggő területek vizsgálatával nem foglalkozik, pedig ezek jogviták alapjait képezhetik majd a környező táblák vízgazdálkodási viszonyainak egyoldalú megváltoztatása miatt.

A tájhasználati optimalizálást segítő jogi eszközök nem jelennek meg az öntözési törvényben, ezek ugyanakkor más jogszabályokon keresztül még biztosíthatók. Fontos továbbá, hogy már az öntözésfejlesztési tervek és a körzeti környezeti tervek kialakításakor a tájhasználat optimalizálási szempont hangsúlyosan megjelenjen a döntések hátterében. Meglátásunk szerint ez nagymértékben segítheti a Víz-keretirányelvnek a vizek jó állapotának elérésére vonatkozó követelményét.

Az egyes tervek által lefedett területek esetében, azok kialakítása során adott esetben szükséges lehet annak előírása, hogy az öntözött területek és a környezetükben található, velük egy talajtársulást, vízgazdálkodási egységet képező táblák talajtani alapú területhasználatát optimalizálják a használói, aminek alapja a talajtani adottságok kötelező vizsgálata. Ez egyébként a korábbi öntözésfejlesztési beruházásokat kísérő, talajvédelmi terveknek is kötelező része volt.

Az öntözésfejlesztési tervek és körzeti környezeti tervek felülvizsgálatának jogszabályi garanciája kardinális kérdés, mind az elővigyázatosság elve, mind pedig a visszalépés tilalmának elve szempontjából. Mint fentebb utaltunk rá, ha komolyan vesszük a fenntarthatóság környezeti dimenzióját is, akkor erre várhatóan gyakran, adott esetben a tervek 20 éves időtartamán belül többször is sor kerülhet majd. Hogy a felülvizsgálat csakugyan megfelelően müködő jogintézmény legyen, nélkülözhetetlen egy több szempontra is kiterjedő monitoringrendszer kiépítése és müködtetése, melynek kötelező eleme kell hogy legyen a termeléssel és a talajállapottal kapcsolatos, kötelezően begyüjtött adatok megosztása és elemzése.

Fontos kitérnünk arra is, hogy meglátásunk szerint a különböző modellezési eljárások eredményeinek átültetését nagyban veszélyeztetheti a Magyarországon je- 
lentős számúnak becsült illegális vízkivételezés. Vagyis ennek felszámolása, illetve mértékének csökkentése az öntözési tervek és területek kialakítása szempontjából is kardinális, más intézkedéssel nem helyettesíthető kérdés.

\section{Következtetések}

Tanulmányunkban a tájszemléletủ koncepció fényében kíséreltük meg elemezni az öntözési törvény által megnyitott, de a döntéshozó (elsődlegesen a Kormány) által még le nem zárt jogalkotási folyamatot. E vonatkozásban fontos hangsúlyozni, hogy a tájszemléletű vízgazdálkodás koncepciója nem valami jogi értelemben kötelező érvényủ elv, amelynek megsértése egy jogszabályt alaptörvény-ellenessé tesz, hanem sokkal inkább egy szakpolitikai iránymutatás, amely számos elemében megjelenik a jelenlegi kormányzat által elfogadott nemzeti vízstratégiában is, és amelynek ugyanakkor vannak olyan vonatkozásai, amelyekhez kapcsolódnak jogi értelemben vett kötőerővel bíró intézmények, mint amilyen a Víz-keretirányelvnek a vizek jó állapotára vonatkozó előírása, vagy az Alkotmánybíróság által kifejlesztett visszalépés tilalmának elve, illetve az elővigyázatosság elve. A még le nem zárt jogalkotási folyamat kapcsán mindenképpen érdemes felhívni a figyelmet arra, hogy annak befejezésénél és müködtetésénél a gazdasági dimenzión túl immáron hangsúlyosabban lenne érdemes figyelembe venni a környezeti dimenziót is. Tanulmányunkban különösen e dimenzió tükrében fogalmaztunk meg jó néhány szempontot és javaslatot. Fontosnak tartjuk megjegyezni, hogy a számos hatósági engedélyt felváltó öntözésfejlesztési terv, illetve környezeti körzeti terv jogintézményének kifejlődése meglátásunk szerint más típusú környezethasználatok (beruházások) esetében is példaként szolgálhat, mintegy a környezeti-természetvédelmi eljárások egyszerüsítésének lehetséges módjaként. Erre tekintettel korántsem mindegy, hogy végső formájában miként nyernek kialakítást ezen intézmények. 